\title{
The elephant in the room: first record of invasive gregarious species of serpulids (calcareous tube annelids) in Majorca (western Mediterranean)
}

\author{
Maël Grosse ${ }^{1}$, Roberto Pérez ${ }^{1}$, Mateo Juan-Amengual ${ }^{1}$, Joan Pons ${ }^{2}$, María Capa ${ }^{1}$ \\ ${ }^{1}$ Departament de Biologia, Universitat de les Illes Balears, Palma, Illes Balears, Spain. \\ (RP) E-mail: robertoperezallende@gmail.com. ORCID iD: https://orcid.org/0000-0002-5333-7307 \\ (MJ-A) E-mail: mateujamengual444@gmail.com. ORCID iD: https://orcid.org/0000-0002-9064-8040 \\ (MC) (Corresponding author) E-mail: maria.capa@uib.es. ORCID iD: https://orcid.org/0000-0002-5063-7961 \\ ${ }^{2}$ Mediterranean Institute for Advanced Studies (IMEDEA), Esporles, Illes Balears, Spain. \\ (JP) E-mail: jpons@imedea.uib-csic.es. ORCID iD: https://orcid.org/0000-0002-4683-8840
}

\begin{abstract}
Summary: Although there are several nuisance species of serpulids reported worldwide, the present study shows that some of them have been overlooked even in geographic areas that are considered well studied. We report for the first time in Majorca the invasive species Ficopomatus enigmaticus and the first records for the Balearic Islands of the also non-native species Hydroides dianthus, $H$. dirampha, H. elegans and $H$. nigra. The most abundant species were $F$. enigmaticus, found at higher densities in Portixol (with up to 280 ind $\mathrm{m}^{-2}$ ), and $H$. elegans, found at highest densities in the port of Palma (with up to 270 ind. $\mathrm{m}^{-2}$ ). Species have been identified after morphological examination and corroborated by mitochondrial DNA sequence data: cytochrome c oxidase subunit 1 (COI) and cytochrome b (Cytb). Molecular data show that the same haplotypes have been found in distant and disjoint biogeographic areas worldwide, which is only explicable by unintentional translocation of specimens through vectors (i.e. ship hulls or ballast water). Species delimitation analyses support previous findings that species complexes are common in both Ficopomatus and Hydroides. In fact, only among the Majorcan samples were we able to detect three species of the $F$. enigmaticus species complex, two of the $H$. elegans species complex and two of the $H$. dianthus species complex. The genetic distances between members of the $F$. enigmaticus species complex are $8.7 \%$ to $16.7 \%$ in COI sequences. The species of Hydroides hold $5.4 \%$ to $47.6 \%$ genetic divergence between species of the same complex.
\end{abstract}

Keywords: non-indigenous; Hydroides, Ficopomatus; Serpulidae; polychaetes; COI; Cytb; integrative taxonomy.

El elefante en la habitación: primera cita de serpúlidos gregarios invasores (anélidos de tubo calcáreo) en Mallorca (Mediterráneo occidental)

Resumen: Hay constancia de especies alóctonas de serpúlidos reportadas en el mundo. Pero el presente estudio muestra que algunas de ellas han sido pasadas por alto incluso en áreas geográficas consideradas bien estudiadas. En este trabajo se cita por primera vez en Mallorca la especie invasora Ficopomatus enigmaticus y se registra también por primera vez para las Islas Baleares las también especies exóticas Hydroides dianthus, H. dirampha, H. elegans e H. nigra. Las especies más abundantes fueron $F$. enigmaticus, encontrada en mayores densidades en Portixol (con hasta $280 \mathrm{ind}^{-2}$ ) y $H$. elegans, encontrada en mayores densidades en el puerto de Palma (con hasta 270 ind. $\mathrm{m}^{-2}$ ). Las especies han sido identificadas después su estudio morfológico y corroboradas por las secuencias de ADN mitocondrial: subunidad 1 de la citocromo c oxidasa (COI) y citocromo b (Cytb). Los datos moleculares muestran que se han encontrado los mismos haplotipos en áreas biogeográficas distantes e inconexas de a nivel mundial, lo que solo se explica por la translocación involuntaria de ejemplares a través de vectores (es decir, cascos de barcos o agua de lastre). Los análisis de delimitación de especies respaldan resultados previos acerca de la existencia de complejos de especies en ambos géneros Ficopomatus e Hydroides. De hecho, sólo entre las muestras mallorquinas pudimos detectar tres especies del complejo de especies $F$. enigmaticus, dos del complejo de especies de $H$. elegans y dos del complejo de especies de $H$. dianthus. Las distancias genéticas entre los miembros del complejo de especies de F. enigmaticus son del 8.7 al $16.7 \%$ en las secuencias COI. Las especies de Hydroides tienen un 5.4-47.6\% de divergencia genética entre especies del mismo complejo.

Palabras clave: alóctonas; Hydroides; Ficopomatus; Serpulidae; poliquetos; COI; Cytb; taxonomía integrativa.

Citation/Como citar este artículo: Grosse M., Pérez R., Juan-Amengual M., Pons J., Capa M. 2021. The elephant in the room: first record of invasive gregarious species of serpulids (calcareous tube annelids) in Majorca (western Mediterranean). Sci. Mar. 85(1): 15-28. https://doi.org/10.3989/scimar.05062.002

Editor: R. Sardà.

Received: April 3, 2020. Accepted: October 19, 2020. Published: March 31, 2021.

Copyright: () 2021 CSIC. This is an open-access article distributed under the terms of the Creative Commons Attribution 4.0 International (CC BY 4.0) License. 


\section{INTRODUCTION}

According to the International Union for Conservation of Nature, biological invasions and destruction of habitat are the most important causes of biodiversity loss. Biological invasions refer to the introduction (accidental or intentional), establishment and expansion of species outside their natural geographic range (ISSG 2011). Non-native species are regarded as a major threat to marine biodiversity and a contributor to environmental change (Bax et al. 2003, Molnar et al. 2008, Katsanevakis et al. 2014). However, introductions have increased radically in recent years due to numerous human-driven activities such as aquaculture, marine traffic and interconnection of hydrogeographic basins. Such introductions, especially if the organisms establish themselves and become invasive, may cause important negative environmental impacts with economic and social implications. Displacement and extinction of local species, hybridization and genetic contamination, alteration of community' structures and complex ecological interaction networks, introduction of parasites and pathogens, obstruction of canals, infrastructure damage and losses in mariculture and facilitation of native species (Rodriguez 2006) are some of the processes that have already been documented as consequences of invasive species (Bax et al. 2003, Zenetos et al. 2005, Molnar et al. 2008).

The family Serpulidae Rafinesque, 1815 are marine, benthic sedentary annelids living in the calcareous tubes they build-a diagnostic feature shared by all members of this family. Serpulids are an important component of the encrusting fauna in benthic environments and can play an important role as ecosystem engineers (Toonen and Pawlik 2001, Wright and Gribben 2017). Non-native serpulid species can therefore cause severe impacts in newly colonized habitats as they can potentially aggregate, forming large biogenic reefs that change the habitat structure (Crooks 2002, Heiman and Micheli 2010, Pernet et al. 2016), reduce food availability for other species (Bruschetti et al. 2009, Pan and Marcoval 2013) and have an effect on sedimentation processes that can change the ecological dynamics (Davies et al. 1989, Schwindt et al. 2001, 2004). Serpulids can also have a more direct impact on human activities by damaging ships or anthropogenic structures in harbours (Ulman et al. 2019) and clogging sewage systems and cooling water in take pipes for power plants (Zibrowius 2002, Read and Gordon 1991, Peria and Pernet 2019).

Ficopomatus enigmaticus (Fauvel, 1923) is a nuisance biofouling organism and a highly invasive species that has colonized estuaries and ports around the planet, where it can build reefs up to several metres in diameter (Fauvel 1923, Dittmann et al. 2009, Styan et al. 2017). It is also the only annelid registered in the Spanish Catalogue of Exotic Invasive Species (http://invasiber.org/). Although its geographical origin is unclear, the most agreed hypothesis is that it spread from Australia or the Indo-Pacific (Dittmann et al. 2009, Styan et al. 2017). The first specimens were discovered in the canals of northern France, were they were probably introduced during World War I, attached to the hulls of warships (Fauvel 1923). The first accurate report for the Iberian Peninsula was in Galicia, northwestern Spain (Rioja 1923), very soon after the species description. Decades later, it was reported in several localities along the Mediterranean coastline and in Turkey, Greece, Italy and Albania (e.g. Ergen 1976, Ambrogi 2000, Shumka et al. 2014). On the Levantine coast of the Iberian Peninsula, F. enigmaticus has been reported from Catalonia, Valencia and Murcia. In the Balearic Islands, it has been found in the Albufera of Menorca forming large reefs (Martínez-Taberner et al. 1993, Fornós et al. 1997) but has never been reported from Majorca.

Seven species of the genus Hydroides, $\mathrm{H}$. dianthus (Verrill, 1873), H. dirampha Mörch, 1863, H. brachyacantha Rioja, 1941, H. elegans (Haswell, 1883), H. heterocera (Grube, 1868), H. minax (Grube, 1878) and H. operculata (Treadwell, 1929), have also been reported as invasive and their presence is well documented for the eastern Mediterranean and for the Levantine coast of the Iberian Peninsula (Çinar 2006, Gil 2011, Alcázar and San Martín 2016, although some of them should be assessed with molecular data). Confirmation of whether a species within the $H$. brachyacantha and $H$. operculata that has already been already assessed or a different one within complexes (Sun et al. 2016, 2017b) is present in Mediterranean waters is still needed, as this was not part of the scope of this study. Hydroides elegans was originally described from Australia and has been reported in many ports and bays all over the world (Gil 2011). Hydroides dirampha described from the Antillean Islands and probably native to the Caribbean (Gil 2011) is a common species in fouling communities of tropical and temperate seas. Hydroides dianthus, described from New England, is also commonly reported in fouling communities of the Atlantic and the Mediterranean coastal environments (Sun et al. 2017a).

Three species were originally described from the Mediterranean: Hydroides pseudouncinata Zibrowius, 1968, Hydroides nigra Zibrowius, 1971 and Hydroides stoichadon Zibrowius, 1971. The former has been commonly reported in several localities of the Mediterranean, including the Balearic Islands and the northeast Atlantic, mainly under the name Hydroides uncinata (Philippi, 1884) (Alcázar and San Martín 2016). Hydroides nigra is considered endemic to the Mediterranean, and has only been reported twice along the Spanish coastline, in Murcia (San Martín and Vieitez 1984) and Majorca (Sun et al. 2017b). Hydroides stoichadon has occasionally been reported in southern France, Italy and Spain (Alcázar and San Martín 1996). Except for H. nigra and H. pseudouncinata, none of the other Hydroides species cited above have yet been reported from the Balearic Islands.

It was not until 2009 that an effort to resolve the species complexes within Serpulidae was made (e.g. Halt et al. 2009, Smith et al. 2012, Willette et al. 2015, and several others thereafter). Among these studies, genetic analyses of $F$. enigmaticus using Cytochrome b 
(Cytb) revealed high genetic diversity in the group and possible cryptic species (Styan et al 2017, Yee et al. 2019, Oliva et al. 2020). Similar patterns were found in some of the species of the genus Hydroides using the markers cytochrome c oxidase subunit 1 (COI) and Cytb (Sun et al. 2016, 2017a). Those findings highlight the importance of DNA-based methods for assessing non-indigenous species.

We present the first record in Majorca of the invasive species $F$. enigmaticus, which is already considered invasive, and the first record for the Balearic Islands of the species $H$. dianthus, $H$. dirampha and $H$. elegans. We also provide results after genetic analyses of DNA sequences and insights about their introduction events and pathways. We refer to the metaphor of the "elephant in the room" in the title, with the aim of highlighting how major issues such as the presence of large populations of marine invasive species have been overlooked in apparently well-known areas such as harbours.

\section{MATERIALS AND METHODS}

\section{Study area and sampling design}

Majorca is the largest island in the Balearic archipelago, located in the western Mediterranean. Its geographical situation has made it a strategic point for trade and exchange with the rest of the Mediterranean since the Phoenician colonies in the third century BC (Aubet 2001), and since the mid-20th century tourism has played a fundamental role in its economy. The archipelago is considered one of the main tourist destinations in Europe, and more than 800 cruise ships and 44000 merchant' ships dock annually in its four main international ports (Palma, Alcudia, Ibiza and Mahón). In addition, Majorca's 30 marinas have over 28000 private docks for pleasure boats (APB 2017). All this maritime traffic has likely caused the involuntary dispersion of adult specimens attached to ship hulls (Zibrowius 1991) or larvae in ballast waters (Hewitt et al. 2009).

Table 1. - Stations and habitats where Ficopomatus and Hydroides species were found in this study.

\begin{tabular}{|c|c|c|c|c|}
\hline $\begin{array}{l}\text { Station } \\
\text { Number }\end{array}$ & Location & Species Found & Depth (m) & Habitat \\
\hline PAR-01 & Port of Palma 39॰34’01.5’N; 2॰38’38.6”'E & H. dianthus & 0.5 & \\
\hline PAR-02 & Puerto de Palma 39॰33'55.7’’N; 2³7'54.7’'E & $\begin{array}{c}\text { F. enigmaticus } \\
\text { H. dianthus } \\
\text { H. elegans }\end{array}$ & 1 & Concrete dock \\
\hline PAR-06 & Port of Palma $39^{\circ} 33^{\prime} 10.4^{\prime \prime} \mathrm{N} ; 2^{\circ} 37^{\prime} 55.4^{\prime \prime} \mathrm{E}$ & H. elegans & 0.5 & \\
\hline PAR-12 & Puerto de Palma 39॰33'55.7’’N; 2³7'54.7’'E & $\begin{array}{c}\text { F. enigmaticus } \\
\text { H. elegans } \\
\text { H. dirampha }\end{array}$ & 1 & Concrete dock \\
\hline POR-01 & Portitxol 39॰33’35.6’'N; 240’05.1’'E & H. dianthus & 1 & \\
\hline POR-02 & Portitxol 39॰33’40.3”N; 240’06.6”E & F. enigmaticus & 0.5 & Concrete dock covered with cirripeds \\
\hline POR-03 & Portitxol 39॰33’42.5’N; $2^{\circ} 40^{\prime} 10.2^{\prime \prime} \mathrm{E}$ & F. enigmaticus & 0.5 & Concrete dock covered with cirripeds \\
\hline POR-04 & Portitxol 39॰33’39.7’’ ; 240’08.3’'E & $\begin{array}{c}\text { F. enigmaticus } \\
\text { H. dianthus }\end{array}$ & 0.3 & Concrete pier with brown algae and sponges \\
\hline POR-12 & Portitxol 39॰33’40.3”N; 240’06.6”E & F. enigmaticus & 0.5 & Concrete dock \\
\hline POR-13 & Portitxol 39॰33’42.5’N; 240’10.2”E & $\begin{array}{c}\text { F. enigmaticus } \\
\text { H. dianthus } \\
\text { H. elegans }\end{array}$ & 0.5 & Concrete dock covered with cirripeds \\
\hline POR-14 & Portitxol 39॰33'39.7’'N; 240’08.3”'E & $\begin{array}{c}\text { F. enigmaticus } \\
\text { H. dianthus } \\
\text { H. nigra }\end{array}$ & 0.3 & Concrete dock with brown algae and sponges \\
\hline PAD-03 & Puerto de Palma 39³3'57.7’'N; 2³7’45.5’'E & F. enigmaticus & 2 & Muddy sediment \\
\hline PABA-14 & Puerto de Palma 39³3'24.0”N; 2³7'32.9'”E & F. enigmaticus & 1 & Fouling plate \\
\hline PALC-01 & Port of Alcudia $39^{\circ} 50 ’ 20.6 ” \mathrm{~N} ; 3^{\circ} 08^{\prime} 03.9^{\prime \prime} \mathrm{E}$ & H. elegans & $0-1$ & Fouling plate \\
\hline PALC-02 & Port of Alcudia $39^{\circ} 50 ’ 21.2^{\prime \prime} \mathrm{N} ; 3^{\circ} 08^{\prime} 01.7^{\prime \prime} \mathrm{E}$ & $\begin{array}{l}\text { H. dianthus } \\
\text { H. elegans }\end{array}$ & $0-1$ & Fouling plate \\
\hline PALC-03 & Port of Alcudia $39^{\circ} 50^{\prime} 22.1^{\prime \prime} \mathrm{N} ; 3^{\circ} 07^{\prime} 57.9^{\prime \prime} \mathrm{E}$ & H. dianthus & $0-1$ & Fouling plate \\
\hline PALC-04 & Port of Alcudia $39^{\circ} 50^{\prime} 13.1^{\prime \prime} \mathrm{N} ; 3^{\circ} 08^{\prime} 06.0^{\prime \prime} \mathrm{E}$ & H. dianthus & $0-1$ & Fouling plate \\
\hline PALC-05 & Port of Alcudia $39^{\circ} 50^{\prime} 14.0{ }^{\prime \prime} \mathrm{N} ; 3^{\circ} 08^{\prime} 06.2^{\prime \prime} \mathrm{E}$ & $\begin{array}{l}\text { H. dianthus } \\
\text { H. dirampha }\end{array}$ & $0-1$ & Fouling plate \\
\hline PALC-06 & Port of Alcudia $39^{\circ} 50^{\prime} 16.1^{\prime \prime} \mathrm{N} ; 3^{\circ} 07^{\prime} 57.6^{\prime \prime} \mathrm{E}$ & $\begin{array}{l}\text { H. dianthus } \\
\text { H. elegans }\end{array}$ & $0-1$ & Fouling plate \\
\hline PALC-07 & Port of Alcudia $39^{\circ} 50^{\prime} 21.6 ” \mathrm{~N} ; 3^{\circ} 08^{\prime} 12.6^{\prime \prime} \mathrm{E}$ & H. dianthus & $0-1$ & Fouling plate \\
\hline PSOL-01 & Port of Sóller $39^{\circ} 47^{\prime} 47.8^{\prime \prime} \mathrm{N} ; 2^{\circ} 41^{\prime} 43.4^{\prime \prime} \mathrm{E}$ & H. dirampha & $0-1$ & Fouling plate \\
\hline
\end{tabular}




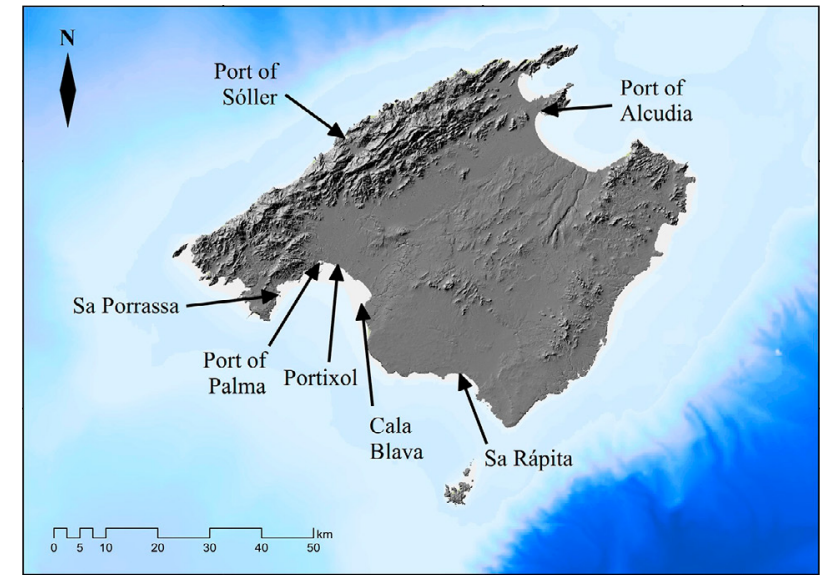

Fig. 1. - Map of the localities sampled around the island of Majorca.

Seven localities were sampled around the island between July 2017 and July 2019 (Fig.1), including the international ports of Palma and Alcudia and the leisure or fishing ports of Sóller, Sa Rápita and Portitxol. In addition, two localities in the bay of Pal- ma but outside the harbour environments were also selected: Sa Porrassa and Cala Blava, in the Marine Reserve of the Bay of Palma. Several samples were taken at each locality, maximizing habitat diversity (exposure, orientation, traffic, type of substrate, etc., Table 1). Modified qualitative rapid assessment surveys (similar to Ulman et al. 2017) were undertaken with a rectangular scraper equipped with a 1 $\mathrm{mm}$ diameter mesh fabric at one end and a $2 \mathrm{~m}$ stick at the other. At each station, artificial substrates were scraped off on the shore to determine the absence or presence of targeted species. Finally, 3 to 5 L sediment samples were collected with a van Veen grab from both anthropogenic and natural environments.

Quantitative samples were also taken by scuba divers (Fig. 2A, B), who scraped a standard surface of $30 \times 30 \mathrm{~cm}$ on hard substrates (both artificial and natural) at depths of 0.5 to $7 \mathrm{~m}$ (Fig. 2A, B). In addition, $33 \times 33 \mathrm{~cm}$ fouling plates were placed at depths of between 0.5 and $5 \mathrm{~m}$ for 3 to 6 months in order to study settlement and colonization processes (Fig. 2D). The surfaces were also scraped after this time.
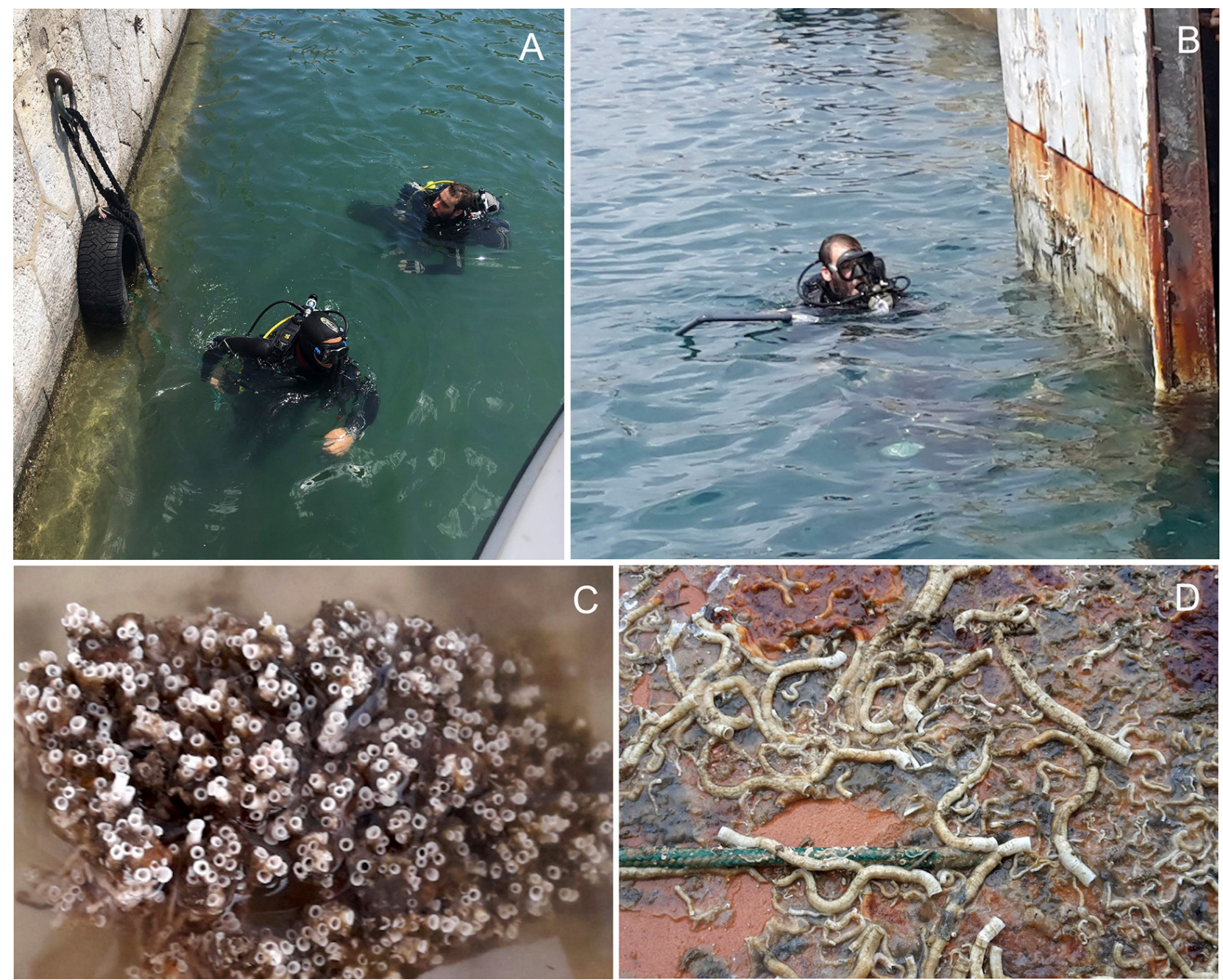

Fig. 2. - A, B, Photographs showing field work and sample collection from harbour environments (port of Palma). C, Ficopomatus enigmaticus aggregation collected from shallow water (1 m deep) in Portixol. D, Hydroides species attached to a fouling plate after four months of being deployed, at port of Palma. 
Target species from all samples were sorted in the laboratory and stored at $4{ }^{\circ} \mathrm{C}$ to $6^{\circ} \mathrm{C}$ in $96 \%$ ethanol. Additional specimens of $H$. norvegica, fixed and preserved in $96 \%$ ethanol, were obtained from Norway for genetic comparison with the morphologically similar $H$. elegans.

The aggregation or colonies present at each locality were considered as populations. A total of 52 specimens of Hydroides and 21 specimens of Ficopomatus were selected from the collected samples for molecular work.

\section{Morphological studies}

All specimens were examined with a stereo and compound light microscope and identified to morphospecies following original and updated descriptions (e.g. Zibrowius 1971, Fauvel 1923, Bastida-Zavala and ten Hove 2002). For scanning electron microscopy (SEM), specimens were dehydrated in a series of mixtures of absolute ethanol and hexamethyldisilazane (HMDS) with the following ratios $3: 1,2: 2,1: 3$, and $1: 1,1: 3$, and then into pure HMDS. The prepared samples were mounted on holders, sputter-coated with gold $(10 \mathrm{~nm}$ thickness) and examined with a HITACHI S-3400N scanning electron microscope at the University of the Balearic Islands. Vouchers were deposited at the Museo Nacional de Ciencias Naturales (MNCN, Madrid; Table 2).

\section{Molecular data}

A small portion, 1 to $2 \mathrm{~mm}$, of each specimen's thorax or a few radioles were taken for molecular work. DNA was extracted from Ficopomatus specimens using the Quick-gDNA Miniprep Kit (Zymo) according to the manufacturer's instructions. DNA was extracted from Hydroides specimens using QuickExtract (Epicentre). Cytochrome c oxydase subunit 1 (COI) and Cytochrome b (Cytb) were amplified by PCR. The amplification reaction of COI for Ficopomatus contained $10.8 \mu \mathrm{l}$ of water, $1.2 \mu \mathrm{l}$ of $50 \mathrm{mM} \mathrm{MgCl}$, $2 \mu \mathrm{l}$ of buffer $10 \times, 0.4 \mu \mathrm{l}$ of Biotaq $5 \mathrm{U} \mathrm{\mu l}^{-1}, 2 \mu \mathrm{lof}$ dNTPs mix at $10 \mathrm{mM}, 0.8 \mu \mathrm{l}$ of each primer jgLCO1490/jgHCO2198 (Geller et al. 2013) at $10 \mathrm{mM}$ and $2 \mu \mathrm{l}$ of DNA (4-20 ng $\mu \mathrm{l}^{-1}$ ). PCR reactions for amplification of Cytb and COI for Hydroides contained $4.5 \mu \mathrm{l}$ of water, $1 \mu \mathrm{l}$ of each primer jgLCO1490/jgHCO2198, Hydro-COIF/Hydro-COIR or Cytb424F/ cobr825, $7.5 \mu \mathrm{l}$ of MyTaq Red Mix (Bioline) and $1 \mu \mathrm{l}$ of DNA (4-20 ng $\mu \mathrm{l}^{-1}$ ). Primer sequences and cycling conditions are given in Table 3. PCR products were run on a $1 \%$ agarose gel containing ethydium bromide for $30 \mathrm{~min}$ at $80 \mathrm{~V}$ and visualized with UV light. Amplified PCR fragments were of around $660 \mathrm{bp}$, while Cytb fragments were of around $430 \mathrm{bp}$. Successful PCR products were cleaned using microCLEAN for PCR clean-up (Microzone) or ethanol/sodium acetate precipitation. For some samples, cycle sequencing was performed on both strands by Eurofins Genomics

Table 2. - Information about the specimens used for the phylogenetic analyses, species names, vouchers, collection information and GenBank accession numbers.

\begin{tabular}{|c|c|c|c|c|c|c|c|c|c|}
\hline Species & Voucher & $\begin{array}{l}\text { DNA } \\
\text { Code }\end{array}$ & $\begin{array}{c}\text { COI } \\
\text { GenBank }\end{array}$ & $\begin{array}{c}\text { Cytb } \\
\text { GenBank }\end{array}$ & Station & $\begin{array}{l}\text { Collection } \\
\text { Date }\end{array}$ & Latitude & ude & Depth \\
\hline Ficopomatus enigmaticus & MNCN 16.01/18765 & FIC01 & MT044486 & MT215015 & POR-02 & 26-Jul-17 & $39^{\circ} 33^{\prime} 40.3^{\prime \prime} \mathrm{N}$ & $2^{\circ} 40^{\prime} 06.6^{\prime \prime} \mathrm{E}$ & $0.5 \mathrm{~m}$ \\
\hline Ficopomatus enigmaticus & MNCN 16.01/18766 & FIC02 & MT044489 & MT215014 & POR-02 & 26-Jul-17 & $39^{\circ} 33^{\prime} 40.3^{\prime \prime} \mathrm{N}$ & $2^{\circ} 40^{\prime} 06.6$ ” E & $0.5 \mathrm{~m}$ \\
\hline Ficopomatus enigmaticus & MNCN 16.01/18767 & FIC04 & MT044492 & NA & POR-03 & 26-Jul-17 & $39^{\circ} 33^{\prime} 42.5^{\prime \prime} \mathrm{N}$ & $2^{\circ} 40^{\prime} 10.2 ” \mathrm{E}$ & $0.5 \mathrm{~m}$ \\
\hline Ficopomatus enigmaticus & MNCN 16.01/18768 & FIC05 & MT044491 & NA & POR-04 & 26-Jul-17 & $39^{\circ} 33^{\prime} 39.7^{\prime \prime} \mathrm{N}$ & $2^{\circ} 40^{\prime} 08.3 ” \mathrm{E}$ & $0.3 \mathrm{~m}$ \\
\hline Ficopomatus enigmaticus & MNCN 16.01/18769 & FIC12 & MT044494 & NA & POR-13 & 28-Nov-17 & $39^{\circ} 33^{\prime} 42.5^{\prime \prime} \mathrm{N}$ & $2^{\circ} 40^{\prime} 10.2 ” \mathrm{E}$ & $0.5 \mathrm{~m}$ \\
\hline Ficopomatus enigmaticus & MNCN 16.01/18770 & FIC15 & MT044488 & NA & POR-14 & $28-N o v-17$ & $39^{\circ} 33^{\prime} 39.7^{\prime \prime} \mathrm{N}$ & $2^{\circ} 40^{\prime} 08.3^{\prime \prime} \mathrm{E}$ & $0.3 \mathrm{~m}$ \\
\hline Ficopomatus enigmaticus & MNCN 16.01/18771 & FIC16 & MT044495 & NA & PAR-12 & 28-Nov-17 & $39^{\circ} 33^{\prime} 55.7^{\prime \prime} \mathrm{N}$ & $2^{\circ} 37^{\prime} 54.7 ’ \mathrm{E}$ & $1 \mathrm{~m}$ \\
\hline Ficopomatus enigmaticus & MNCN 16.01/18772 & FIC17 & MT044490 & NA & & 28-Nov-17 & $39^{\circ} 33^{\prime} 55.7^{\prime \prime} \mathrm{N}$ & $2^{\circ} 37^{\prime} 54.7^{\prime \prime} \mathrm{E}$ & $1 \mathrm{~m}$ \\
\hline Ficopomatus enigmaticus & MNCN 16.01/18773 & FIC20 & MT044487 & NA & PAR-12 & 28-Nov-17 & $39^{\circ} 33^{\prime} 55.7^{\prime \prime} \mathrm{N}$ & $2^{\circ} 37^{\prime} 54.7^{\prime \prime} \mathrm{E}$ & $1 \mathrm{~m}$ \\
\hline Ficopomatus enigmaticus & MNCN 16.01/18774 & FIC21 & MT044493 & NA & POR-13 & 28-Nov-17 & $39^{\circ} 33^{\prime} 42.5^{\prime \prime} \mathrm{N}$ & $2^{\circ} 40^{\prime} 10.2^{\prime \prime} \mathrm{E}$ & $0.5 \mathrm{~m}$ \\
\hline Hydroides nigra & MNCN 16.01/18775 & HYD11 & NA & MT215009 & PAR-06 & 26-Jul-17 & $39^{\circ} 33^{\prime} 10.4^{\prime \prime} \mathrm{N}$ & $2^{\circ} 37^{\prime} 55.4^{\prime \prime} \mathrm{E}$ & $0.5 \mathrm{~m}$ \\
\hline Hydroides dianthus & MNCN 16.01/18776 & HYD14 & NA & MT215010 & PALC-02 & 26-Jul-17 & $39^{\circ} 50^{\prime} 21.2^{\prime \prime} \mathrm{N}$ & $3^{\circ} 08^{\prime} 01.7^{\prime \prime} \mathrm{E}$ & $0.5 \mathrm{~m}$ \\
\hline Hydroides elegans & & HYD22 & NA & MT215012 & PARBAL-15 & 28-Nov-17 & $39^{\circ} 33^{\prime} 15.5^{\prime \prime} \mathrm{N}$ & $2^{\circ} 37^{\prime} 33.7 ’ \mathrm{E}$ & \\
\hline Hydroides elegans & MNCN 16.01/18777 & HYD23 & NA & MT215008 & PAR-02 & 26-Jul-17 & $39^{\circ} 33^{\prime} 55.7^{\prime \prime} \mathrm{N}$ & $2^{\circ} 37^{\prime} 54.7^{\prime \prime} \mathrm{E}$ & $1 \mathrm{~m}$ \\
\hline Hydroides dianthus & MNCN 16.01/18778 & HYD26 & NA & MT215011 & PAR-01 & 26-Jul-17 & $39^{\circ} 34^{\prime} 01.5^{\prime \prime} \mathrm{N}$ & $2^{\circ} 38^{\prime} 38.6^{\prime \prime} \mathrm{E}$ & $0.5 \mathrm{~m}$ \\
\hline Hydroides norvegica & & HYD30 & NA & MT215013 & BER-FASCD2 & 10-Sep-18 & 60.40017 & 5.30842 & $12 \mathrm{~m}$ \\
\hline Hydroides dirampha & MNCN 16.01/18779 & PAR06i05 & MT044496 & NA & PAR-06 & 26-Jul-17 & $39^{\circ} 33^{\prime} 10.4{ }^{\prime \prime} \mathrm{N}$ & $2^{\circ} 37^{\prime} 55.4^{\prime \prime} \mathrm{E}$ & $0.5 \mathrm{~m}$ \\
\hline Hydroides dianthus & MNCN 16.01/18780 & POR02i09 & MT044497 & NA & POR-02 & 26-Jul-17 & $39^{\circ} 33^{\prime} 40.3^{\prime \prime} \mathrm{N}$ & $2^{\circ} 40^{\prime} 06.6 ” \mathrm{E}$ & $0.5 \mathrm{~m}$ \\
\hline Hydroides elegans & MNCN 16.01/18781 & PAR02i05 & MT044498 & NA & PAR-02 & 26-Jul-17 & $39^{\circ} 33^{\prime} 55.7^{\prime} \mathrm{N}$ & $2^{\circ} 37^{\prime} 54.7 ’ \mathrm{E}$ & $1 \mathrm{~m}$ \\
\hline Hydroides elegans & MNCN 16.01/18782 & PAR02i04 & MT044499 & NA & PAR-02 & 26-Jul-17 & $39^{\circ} 33^{\prime} 55.7^{\prime \prime} \mathrm{N}$ & $2^{\circ} 37^{\prime} 54.7^{\prime \prime} \mathrm{E}$ & $1 \mathrm{~m}$ \\
\hline Hydroides elegans & MNCN 16.01/18783 & PAD01i03 & MT044500 & NA & PAD-01 & 26-Jul-17 & $39^{\circ} 34^{\prime} 01.5^{\prime \prime} \mathrm{N}$ & $2^{\circ} 38^{\prime} 38.6^{\prime \prime} \mathrm{E}$ & $2 \mathrm{~m}$ \\
\hline Hydroides elegans & MNCN 16.01/18784 & PAR02i08 & MT044501 & NA & PAR-02 & 26-Jul-17 & $39^{\circ} 33^{\prime} 55.7^{\prime \prime} \mathrm{N}$ & $2^{\circ} 37^{\prime} 54.7^{\prime \prime} \mathrm{E}$ & $1 \mathrm{~m}$ \\
\hline
\end{tabular}


DNA Sequencing Department (Ebersberg, Germany). The rest of the samples were terminated using BigDye Terminator v3.1 (ThermoFisher) and sequenced on an ABI3130 sequencer. Forward and reverse reads were merged into consensus sequences and edited using Geneious v.7 (Kearse et al. 2012).

Additionally, $57 \mathrm{COI}$ and $42 \mathrm{Cytb}$ sequences of $F$. enigmaticus and Hydroides spp. were downloaded from GenBank (Benson et al. 2008, see Supplementary Material).

\section{Phylogenetic and species delimitation analysis and genetic distances}

Sequences were aligned with MAFFT 7 online version (Katoh and Standley 2013) and alignments were checked in Aliview 1.25 (Larsson 2014). Flanking regions with missing data were removed using Gblocks 0.91b (Castresana 2000) with the softest parameters (allow for smaller final blocks, gap positions within the final blocks and less strict flanking positions).

Best-fitting models and partition schema for each marker were selected using PartionFinder 2.1.1 (Lanfear et al. 2016, Guindon et al. 2010) with the Bayesian information criterion. The number of variable and parsimony-informative sites was calculated with MEGA X 10.0.5 (Kumar et al. 2018). Two datasets were created for phylogenetic analyses: one containing unique COI sequences and one containing unique $\mathrm{Cytb}$ sequences.

Bayesian inference (BI) analyses were performed on both datasets to obtain ultrametric trees compatible with downstream species delimitation analyses. BI analyses were conducted using BEAST2 (Bouckaert et al. 2014) for both datasets (COI and the concatenated dataset) using the nucleotide substitution model mentioned above. A strict clock was assumed for both datasets. A Yule model was used as tree prior with a default $\Gamma$ distribution as birth rate prior. A lognormal distribution with $\mathrm{M}=1.0$ and $\mathrm{S}=1.25$ was used for the kappa parameter prior (Drummond and Bouckaert 2015). All analyses were run with a chain length of 50000000. Convergence of each run and parameter was checked using Tracer 1.7.1
(Rambaut et al. 2018), i.e. ESS > 200. A maximum clade credibility tree was obtained with Treeannotator (Bouckaert et al. 2014) after discarding 25\% of the trees as burnin. All phylogenetic analyses were performed on Cypres Science Gateway (Miller et al. 2010). Trees were visualized and edited using FigTree 1.4.4 (Rambaut 2014) and later in LibreOffice Draw 5.1.6.2.

The general mixed Yule-coalescent model (GMYC) (Pons et al. 2006, Fujisawa and Barraclough 2013) and the multi-rate Poisson tree process (mPTP) (Kapli et al. 2017) were used to delimit the number of molecular species in the datasets. GMYC and MPTP 0.2.4 were used on both BI trees with a single threshold. The methods were applied separately on the Ficopomatus and Hydroides groups for the Cytb datasets. GMYC was implemented in R (R Core Team 2015) with the packages ape 5.3 (Paradis and Schliep 2018), MASS 7.3-45 Venables and Ripley 2002), Paran 1.5.2 (Dinno 2018) and splits 1.019 (Ezard et al. 2017). mPTP was applied through its webserver (https://mptp.h-its.org).

Nucleotide divergence (K2P) over sequence pairs within and between the well supported lineages after the phylogenetic analyses and species delimitation analyses were estimated in MEGA X 10.0.5 (Kumar et al. 2018). Paired positions containing gaps and missing data were removed.

\section{RESULTS}

\section{Morphological analyses and records}

The presence of F. enigmaticus was confirmed in two of the seven sampled areas: the port of Palma and Portixol (Fig. 2C). In the port of Palma, it was only found on one of the deployed fouling plates. Scrapings in Portixol recovered aggregations of at least 280 individuals $/ \mathrm{m}^{2}$ at some sites, especially those closed to the torrent mouth, right at the end of the port. Four species of Hydroides were identified morphologically from the ports of Palma, Portixol, Alcudia and Sóller: $H$. dianthus, $H$. elegans, $H$. dirampha and $H$. nigra (Figs. 2D, 3). These five serpulid species are recorded for the first time in Majorca. Juvenile or damaged

Table 3. - Primers used in this study with their respective cycles.

\begin{tabular}{|c|c|c|c|c|}
\hline Marker & Primers & Source & Sequence & Cycle \\
\hline \multirow{2}{*}{ COI } & jgLCO1490 & (Geller et al. 2013) & TITCIACIAAYCAYAARGAYATTGG & $\begin{array}{l}4 \min 95^{\circ} \mathrm{C} \\
34 \mathrm{x}: 40 \mathrm{~s} 94^{\circ} \mathrm{C} \\
40 \mathrm{~s} 48^{\circ} \mathrm{C}, 60 \mathrm{~s} \\
72^{\circ} \mathrm{C} \\
6 \mathrm{~min} 72^{\circ} \mathrm{C}\end{array}$ \\
\hline & Hydro-COIF & (Sun et al. 2012) & $\begin{array}{l}\text { TCWRTWRTKACDGTKCATGCTA } \\
\text { CMRYAGGWTSAAARAACCTAGTA }\end{array}$ & $\begin{array}{l}5 \min 95^{\circ} \mathrm{C} \\
35 \mathrm{x} 40 \mathrm{~s} 94^{\circ} \mathrm{C} \\
40 \mathrm{~s} 48^{\circ} \mathrm{C}, 60 \mathrm{~s} \\
72^{\circ} \mathrm{C} ; 6 \mathrm{~min} \\
72^{\circ} \mathrm{C}\end{array}$ \\
\hline Cytb & $\begin{array}{l}\text { Cytb 424F } \\
\text { cobr825 }\end{array}$ & $\begin{array}{l}\text { (Boore and Brown 2000) } \\
\text { (Burnette et al. 2005) }\end{array}$ & $\begin{array}{l}\text { GGWTAYGTWYTWCCWTGRGGWCARAT } \\
\text { AARTAYCAYTCYGGYTTRATRTG }\end{array}$ & $\begin{array}{l}4 \min 95^{\circ} \mathrm{C} ; 35 \mathrm{x} \\
40 \mathrm{~s} 94^{\circ} \mathrm{C}, 40 \mathrm{~s} \\
50^{\circ} \mathrm{C}, 60 \mathrm{~s} 72^{\circ} \mathrm{C} ; \\
6 \min 72^{\circ} \mathrm{C} \\
\end{array}$ \\
\hline
\end{tabular}


specimens without an operculum could not be identified to the species level. The most common and abundant species was $H$. elegans, which was found in the port of Palma at densities of up to 270 individuals $/ \mathrm{m}^{2}$. No Hydroides specimens were found in the ports of Sa Rápita and Cala Blava and only one specimen of one species, $H$. nigra, was collected at the Islet of Sa Porrassa (donated to Sun et al. 2017b). Specimens identified as $H$. norvegica from Norway were compared morphologically with $H$. elegans to confirm that the main morphological differences are in the collar chaetae, with subdistal spines in the latter absent in the former. The wide variation observed in the opercular morphology of members of both species indicates that this is a less reliable character for species discrimination.

\section{Phylogenetic and species delimitation analyses}

Despite our efforts to amplify and sequence both markers, only $10 \mathrm{COI}$ and two Cytb sequences of F. enigmaticus were obtained (GenBank accession numbers (AC): MT044486-MT044495, MT215014MT215015; Table 2), as well as six COI and five Cytb sequences of Hydroides (AC: MT044496MT044501, MT215008-MT215013; Table 2). The COI dataset contained 68 sequences and was $379 \mathrm{bp}$ long, with 228 variable sites, 212 of them parsimony-informative. The Cytb dataset contained 50 sequences and was 264 bp long, with 190 variable sites, 175 of them parsimony-informative.

Specimens of $F$. enigmaticus split into three distinct and supported clades, and species delimitation analyses (GMYC and mPTP) confirmed the presence of three molecular species of the $F$. enigmaticus species complex in Majorca. For two species, F. enigmaticus Clade 4 and 5 (Fig. 4), only COI sequences are available and do not match any existing records. Therefore, these species could be new cryptic species within the $F$. enigmaticus complex, or else could match any of the clades previously assessed in Australia (Styan et al. 2017). For the third species, $F$. enigmaticus Clade 1 (Fig 4, 5), both COI and Cytb sequences are available, and this species has previously been recorded from distant bioregions such as Australia, New Zealand, California and Portugal and northern Spain (e.g. Styan et al. 2017, Yee et al. 2019, Oliva et al. 2020). K2P distances within these species range from $0.3 \%$ to $4.7 \%$, and $\mathrm{K} 2 \mathrm{P}$ distances between them range from $10.5 \%$ to $24.7 \%$ (Tables $4,5)$.

Among specimens identified as Hydroides elegans, two species are recovered after phylogenetic and species delimitation analyses. For one species, H. elegans Clade E2 (Fig 4), only COI sequences are available, and do not match any existing records. Therefore, this species appears to be a new cryptic species within the $H$. elegans species complex. For the second species, $H$. elegans Clade E1 (Figs 4, 5), both COI and Cytb sequences are available (albeit from different specimens). This species has previously been recorded from distant bioregions such as

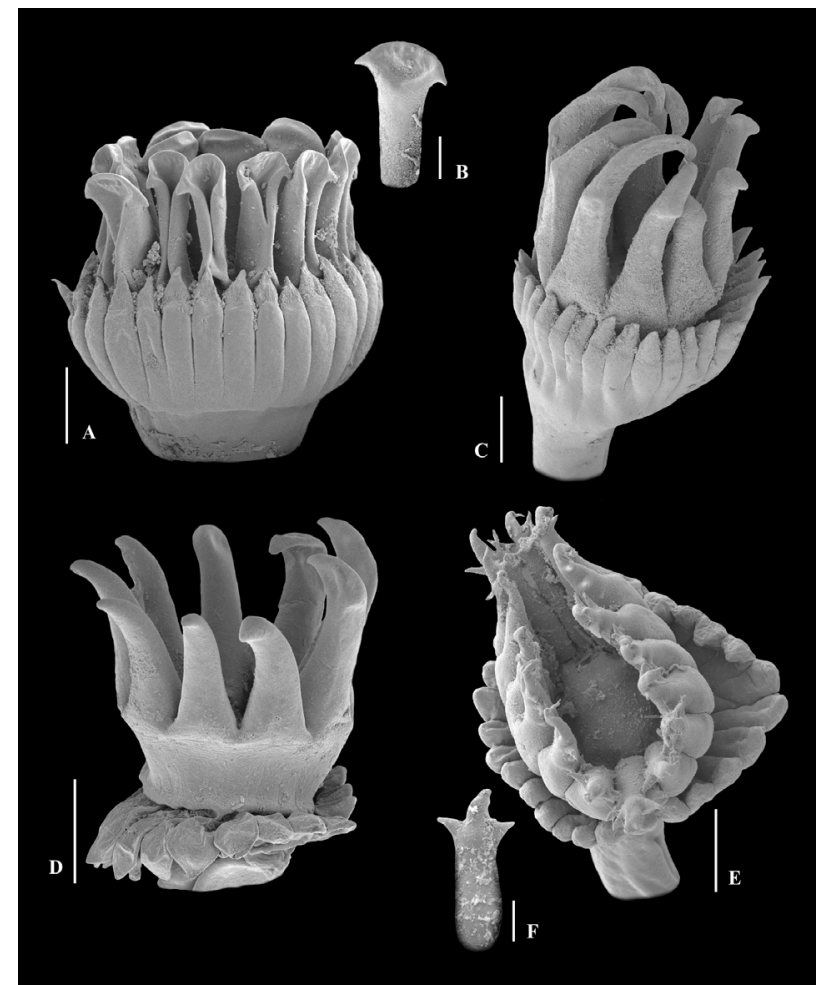

Fig. 3. - SEM pictures of the operculum of the four species of Hydroides recorded. A, H. dirampha, scale bar $200 \mu \mathrm{m} ; \mathrm{B}$, detail of operculum of H. dirampha, scale bar $100 \mu \mathrm{m} ; \mathrm{C}, H$. nigra, scale bar $200 \mu \mathrm{m} ; \mathrm{D}, H$. dianthus, scale bar $200 \mu \mathrm{m}$; E, H. elegans, scale bar $100 \mu \mathrm{m} ; \mathrm{F}$, detail of operculum of $H$. elegans, scale bar $50 \mu \mathrm{m}$.

Australia, California and China. K2P distances within these species range from $0.07 \%$ to $1.4 \%$, and $\mathrm{K} 2 \mathrm{P}$ distances from other Hydroides species range from $9.2 \%$ to $46.3 \%$ (Tables 4,5 ).

Among the specimens identified as Hydroides dirampha, one species was recovered with one COI sequence available (Fig. 4). This species has previously been recorded from distant bioregions such as Australia and Panama. K2P distances from other $\mathrm{Hy}$ droides species range from $21.9 \%$ to $31.3 \%$ (Tables 4, 5).

Among the specimens identified as Hydroides dianthus, two species were recovered. For one species, $H$. diantus Clade A (Fig. 4), one COI sequence is available. This species has been previously identified from the Mediterranean, as well as from distant bioregions such as China, Brazil and the east coast of the US. For the other species, $H$. dianthus Clade B (Fig. 5), one Cytb sequences was available. This species has previously been recorded from distant bioregions such as Ukraine and Texas. K2P distances within these species range from $0.08 \%$ to $1.7 \%$, and $\mathrm{K} 2 \mathrm{P}$ distances from other Hydroides species range from $6.7 \%$ to $34.2 \%$ (Tables 4,5 ).

One Cytb sequence was obtained from the specimen identified as $H$. nigra, which does not cluster with any available sequences, including that of another specimen identified as $H$. nigra from Majorca (Fig. 5). K2P distances from other Hydroides species 
Table 4. - Divergences measured in COI fragment using the K2P model (lower left corner) and p-distance (upper right corner). In grey cells, intraspecific genetic variation (K2P). Ambiguous positions removed for each sequence pair.

\begin{tabular}{|c|c|c|c|c|c|c|c|c|c|c|c|c|c|c|c|c|c|c|c|c|c|c|c|}
\hline COI & 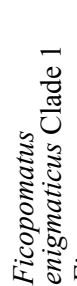 & 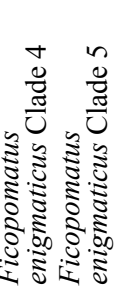 & 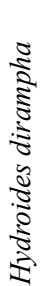 & 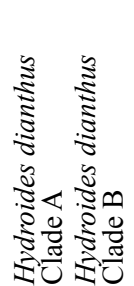 & 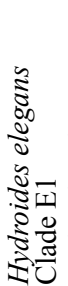 & 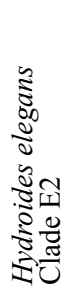 & 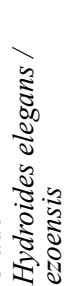 & 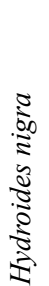 & 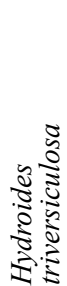 & 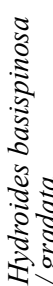 & 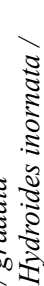 & 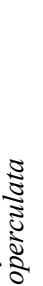 & $\frac{3}{8}$ & & 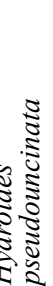 & 5 & & 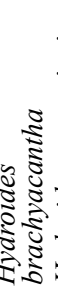 & 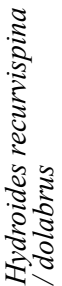 & & & 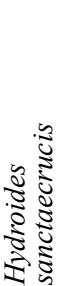 & 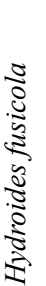 \\
\hline
\end{tabular}

\begin{tabular}{lllllllllllllllllllllllll}
\hline Ficopomatus enigmaticus Clade 1 & 0.02 & 0.11 & 0.16 & 0.58 & 0.61 & 0.59 & 0.56 & 0.51 & 0.58 & 0.61 & 0.63 & 0.56 & 0.52 & 0.57 & 0.62 & 0.63 & 0.60 & 0.60 & 0.59 & 0.58 & 0.59
\end{tabular}

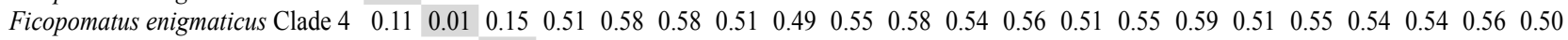

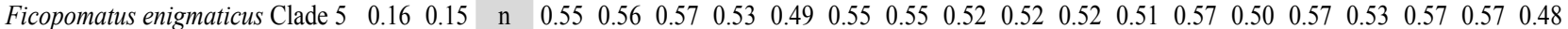
Hydroides dirampha Hydroides dianthus Clade $\mathrm{A}$ Hydroides dianthus Clade $\mathrm{B}$ Hydroides elegans Clade E1 Hydroides elegans Clade $\mathrm{E} 2$ Hydroides elegans / ezoensis Hydroides nigra Hydroides triversiculosa Hydroides basispinosa / gradata Hydroides inornata / operculata Hydroides operculata Hydroides pseudouncinata Hydroides crucigera Hydroides brachyacantha Hydroides recurvispina / dolabrus Hydroides panamensis Hydroides sanctaecrucis Hydroides fusicola $\begin{array}{lllllllllllllllllllll}0.58 & 0.51 & 0.55 & \mathrm{n} & 0.25 & 0.27 & 0.31 & 0.29 & 0.29 & 0.31 & 0.29 & 0.30 & 0.28 & 0.29 & 0.30 & 0.24 & 0.22 & 0.25 & 0.23 & 0.23 & 0.28\end{array}$ $\begin{array}{lllllllllllllllllllll}0.61 & 0.58 & 0.56 & 0.25 & 0.01 & 0.07 & 0.31 & 0.30 & 0.24 & 0.32 & 0.32 & 0.31 & 0.28 & 0.30 & 0.28 & 0.24 & 0.19 & 0.17 & 0.20 & 0.15 & 0.25\end{array}$ $\begin{array}{lllllllllllllllllllll}0.59 & 0.58 & 0.57 & 0.27 & 0.07 & 0.01 & 0.29 & 0.30 & 0.26 & 0.32 & 0.31 & 0.31 & 0.30 & 0.33 & 0.26 & 0.24 & 0.23 & 0.18 & 0.21 & 0.14 & 0.28\end{array}$ $\begin{array}{lllllllllllllllllllll}0.56 & 0.51 & 0.53 & 0.31 & 0.31 & 0.29 & 0.01 & 0.09 & 0.30 & 0.32 & 0.30 & 0.29 & 0.31 & 0.35 & 0.36 & 0.29 & 0.32 & 0.28 & 0.31 & 0.30 & 0.31\end{array}$ $\begin{array}{lllllllllllllllllllll}0.51 & 0.49 & 0.49 & 0.29 & 0.30 & 0.30 & 0.09 & 0.01 & 0.28 & 0.32 & 0.30 & 0.26 & 0.27 & 0.32 & 0.31 & 0.26 & 0.30 & 0.26 & 0.27 & 0.29 & 0.28\end{array}$ $\begin{array}{lllllllllllllllllllll}0.58 & 0.55 & 0.55 & 0.29 & 0.24 & 0.26 & 0.30 & 0.28 & 0.00 & 0.29 & 0.30 & 0.24 & 0.25 & 0.28 & 0.30 & 0.27 & 0.26 & 0.29 & 0.31 & 0.28 & 0.11\end{array}$ \begin{tabular}{llllllllll|lllllllllll}
0.61 & 0.58 & 0.55 & 0.31 & 0.32 & 0.32 & 0.32 & 0.32 & 0.29 & $\mathrm{n}$ & 0.30 & 0.27 & 0.26 & 0.29 & 0.20 & 0.28 & 0.30 & 0.30 & 0.29 & 0.30 & 0.30
\end{tabular} $\begin{array}{llllllllllllllllllllll}0.63 & 0.54 & 0.52 & 0.29 & 0.32 & 0.31 & 0.30 & 0.30 & 0.30 & 0.30 & \mathrm{n} & 0.34 & 0.35 & 0.35 & 0.29 & 0.27 & 0.28 & 0.31 & 0.31 & 0.29 & 0.29\end{array}$ $\begin{array}{lllllllllllllllllllll}0.56 & 0.56 & 0.52 & 0.30 & 0.31 & 0.31 & 0.29 & 0.26 & 0.24 & 0.27 & 0.34 & 0.00 & 0.15 & 0.20 & 0.26 & 0.26 & 0.30 & 0.31 & 0.29 & 0.30 & 0.26\end{array}$ $\begin{array}{lllllllllllllllllllll}0.52 & 0.51 & 0.52 & 0.28 & 0.28 & 0.30 & 0.31 & 0.27 & 0.25 & 0.26 & 0.35 & 0.15 & 0.00 & 0.10 & 0.25 & 0.24 & 0.24 & 0.26 & 0.26 & 0.25 & 0.27\end{array}$ $\begin{array}{lllllllllllllllllllll}0.57 & 0.55 & 0.51 & 0.29 & 0.30 & 0.33 & 0.35 & 0.32 & 0.28 & 0.29 & 0.35 & 0.20 & 0.10 & \mathrm{n} & 0.25 & 0.25 & 0.26 & 0.28 & 0.29 & 0.27 & 0.27\end{array}$ $\begin{array}{lllllllllllllllllllll}0.62 & 0.59 & 0.57 & 0.30 & 0.28 & 0.26 & 0.36 & 0.31 & 0.30 & 0.20 & 0.29 & 0.26 & 0.25 & 0.25 & 0.01 & 0.23 & 0.21 & 0.24 & 0.25 & 0.23 & 0.31\end{array}$ $\begin{array}{lllllllllllllllllllll}0.63 & 0.51 & 0.50 & 0.24 & 0.24 & 0.24 & 0.29 & 0.26 & 0.27 & 0.28 & 0.27 & 0.26 & 0.24 & 0.25 & 0.23 & \mathrm{n} & 0.22 & 0.23 & 0.21 & 0.22 & 0.26\end{array}$ $\begin{array}{lllllllllllllllllllll}0.60 & 0.55 & 0.57 & 0.22 & 0.19 & 0.23 & 0.32 & 0.30 & 0.26 & 0.30 & 0.28 & 0.30 & 0.24 & 0.26 & 0.21 & 0.22 & \mathrm{n} & 0.18 & 0.18 & 0.16 & 0.26\end{array}$ $\begin{array}{lllllllllllllllllllll}0.60 & 0.54 & 0.53 & 0.25 & 0.17 & 0.18 & 0.28 & 0.26 & 0.29 & 0.30 & 0.31 & 0.31 & 0.26 & 0.28 & 0.24 & 0.23 & 0.18 & 0.00 & 0.14 & 0.15 & 0.27\end{array}$ $\begin{array}{lllllllllllllllllllll}0.59 & 0.54 & 0.57 & 0.23 & 0.20 & 0.21 & 0.31 & 0.27 & 0.31 & 0.29 & 0.31 & 0.29 & 0.26 & 0.29 & 0.25 & 0.21 & 0.18 & 0.14 & 0.03 & 0.18 & 0.29\end{array}$ $\begin{array}{lllllllllllllllllllll}0.58 & 0.56 & 0.57 & 0.23 & 0.15 & 0.14 & 0.30 & 0.29 & 0.28 & 0.30 & 0.29 & 0.30 & 0.25 & 0.27 & 0.23 & 0.22 & 0.16 & 0.15 & 0.18 & 0.01 & 0.27\end{array}$ \begin{tabular}{llllllllllllllllllllll}
0.59 & 0.50 & 0.48 & 0.28 & 0.25 & 0.28 & 0.31 & 0.28 & 0.11 & 0.30 & 0.29 & 0.26 & 0.27 & 0.27 & 0.31 & 0.26 & 0.26 & 0.27 & 0.29 & 0.27 & $n$ \\
\hline
\end{tabular}

Table 5. - Divergences measured in Cytb fragment using the K2P model (lower left corner) and p-distance (upper right corner). In grey cells, intraspecific genetic variation (K2P). Ambiguous positions removed for each sequence pair.

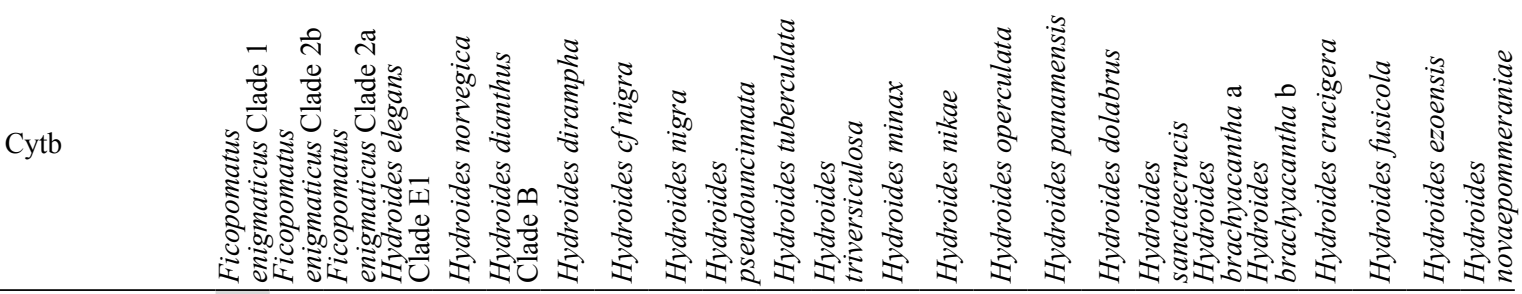

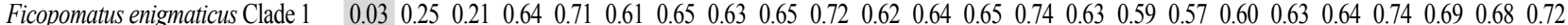
Ficopomatus enigmaticus Clade 2b $\begin{array}{lllllllllllllllllllllllllllll}0.25 & 0.00 & 0.19 & 0.72 & 0.70 & 0.64 & 0.67 & 0.66 & 0.68 & 0.77 & 0.68 & 0.65 & 0.66 & 0.73 & 0.68 & 0.63 & 0.63 & 0.60 & 0.67 & 0.69 & 0.76 & 0.72 & 0.78 & 0.70\end{array}$

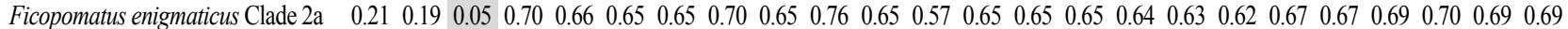
$\begin{array}{lllllllllllllllllllllllll}\text { Hydroides elegans Clade E1 } & 0.64 & 0.72 & 0.70 & 0.01 & 0.26 & 0.44 & 0.38 & 0.46 & 0.43 & 0.42 & 0.40 & 0.40 & 0.37 & 0.41 & 0.43 & 0.37 & 0.44 & 0.40 & 0.38 & 0.35 & 0.43 & 0.43 & 0.40 & 0.46\end{array}$ Hydroides norvegica Hydroides dianthus Clade B Hydroides dirampha Hydroides cf nigra Hydroides nigra Hydroides pseudouncinnata Hydroides tuberculata Hydroides triversiculosa Hydroides minax Hydroides nikae Hydroides operculata Hydroides panamensis Hydroides dolabrus Hydroides sanctaecrucis Hydroides brachyacantha a Hydroides brachyacantha $\mathrm{b}$ Hydroides crucigera Hydroides fusicola Hydroides ezoensis Hydroides novaepommeraniae $\begin{array}{llllllllllllllllllllllll}0.71 & 0.70 & 0.66 & 0.26 & 0.04 & 0.41 & 0.42 & 0.45 & 0.47 & 0.43 & 0.43 & 0.36 & 0.38 & 0.39 & 0.44 & 0.36 & 0.36 & 0.37 & 0.39 & 0.36 & 0.42 & 0.36 & 0.41 & 0.43\end{array}$

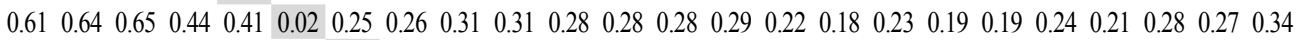
$\begin{array}{llllllllllllllllllllllll}0.65 & 0.67 & 0.65 & 0.38 & 0.42 & 0.25 & \mathrm{n} & 0.22 & 0.26 & 0.26 & 0.27 & 0.23 & 0.26 & 0.28 & 0.23 & 0.17 & 0.19 & 0.22 & 0.22 & 0.19 & 0.25 & 0.34 & 0.26 & 0.30\end{array}$

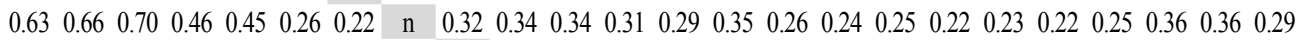
$\begin{array}{llllllllllllllllllllllll}0.65 & 0.68 & 0.65 & 0.43 & 0.47 & 0.31 & 0.26 & 0.32 & \mathrm{n} & 0.22 & 0.34 & 0.31 & 0.35 & 0.29 & 0.27 & 0.29 & 0.34 & 0.31 & 0.31 & 0.30 & 0.31 & 0.42 & 0.35 & 0.38\end{array}$ $\begin{array}{lllllllllllllllllllllllll}0.72 & 0.77 & 0.76 & 0.42 & 0.43 & 0.31 & 0.26 & 0.34 & 0.22 & \mathrm{n} & 0.36 & 0.30 & 0.29 & 0.29 & 0.27 & 0.27 & 0.29 & 0.27 & 0.32 & 0.30 & 0.27 & 0.37 & 0.29 & 0.36\end{array}$ $\begin{array}{llllllllllllllllllllllll}0.62 & 0.68 & 0.65 & 0.40 & 0.43 & 0.28 & 0.27 & 0.34 & 0.34 & 0.36 & 0.19 & 0.30 & 0.25 & 0.26 & 0.28 & 0.25 & 0.25 & 0.26 & 0.27 & 0.29 & 0.29 & 0.30 & 0.27 & 0.30\end{array}$

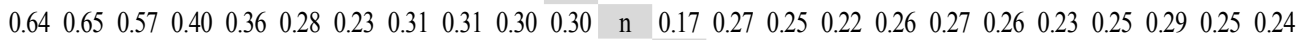

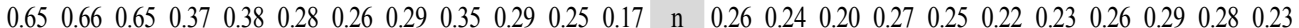
$\begin{array}{lllllllllllllllllllllllll}0.74 & 0.73 & 0.65 & 0.41 & 0.39 & 0.29 & 0.28 & 0.35 & 0.29 & 0.29 & 0.26 & 0.27 & 0.26 & 0.00 & 0.26 & 0.22 & 0.27 & 0.29 & 0.27 & 0.28 & 0.27 & 0.32 & 0.29 & 0.33\end{array}$ $\begin{array}{llllllllllllllllllllllll}0.63 & 0.68 & 0.65 & 0.43 & 0.44 & 0.22 & 0.23 & 0.26 & 0.27 & 0.27 & 0.28 & 0.25 & 0.24 & 0.26 & \mathrm{n} & 0.16 & 0.24 & 0.21 & 0.18 & 0.21 & 0.27 & 0.34 & 0.32 & 0.29\end{array}$

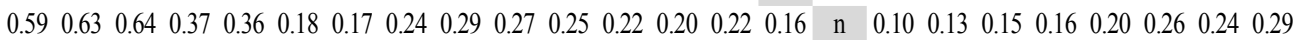
$\begin{array}{llllllllllllllllllllllll}0.57 & 0.63 & 0.63 & 0.44 & 0.36 & 0.23 & 0.19 & 0.25 & 0.34 & 0.29 & 0.25 & 0.26 & 0.27 & 0.27 & 0.24 & 0.10 & \mathrm{n} & 0.17 & 0.19 & 0.23 & 0.24 & 0.28 & 0.24 & 0.30\end{array}$ $\begin{array}{llllllllllllllllllllllll}0.60 & 0.60 & 0.62 & 0.40 & 0.37 & 0.19 & 0.22 & 0.22 & 0.31 & 0.27 & 0.26 & 0.27 & 0.25 & 0.29 & 0.21 & 0.13 & 0.17 & \mathrm{n} & 0.17 & 0.21 & 0.21 & 0.24 & 0.25 & 0.28\end{array}$ $\begin{array}{llllllllllllllllllllllll}0.63 & 0.67 & 0.67 & 0.38 & 0.39 & 0.19 & 0.22 & 0.23 & 0.31 & 0.32 & 0.27 & 0.26 & 0.22 & 0.27 & 0.18 & 0.15 & 0.19 & 0.17 & 0.00 & 0.19 & 0.21 & 0.29 & 0.28 & 0.31\end{array}$ $\begin{array}{lllllllllllllllllllllllllll}0.64 & 0.69 & 0.67 & 0.35 & 0.36 & 0.24 & 0.19 & 0.22 & 0.30 & 0.30 & 0.29 & 0.23 & 0.23 & 0.28 & 0.21 & 0.16 & 0.23 & 0.21 & 0.19 & 0.00 & 0.22 & 0.29 & 0.26 & 0.32\end{array}$ $\begin{array}{llllllllllllllllllllllll}0.74 & 0.76 & 0.69 & 0.43 & 0.42 & 0.21 & 0.25 & 0.25 & 0.31 & 0.27 & 0.29 & 0.25 & 0.26 & 0.27 & 0.27 & 0.20 & 0.24 & 0.21 & 0.21 & 0.22 & \mathrm{n} & 0.30 & 0.27 & 0.35\end{array}$ $\begin{array}{llllllllllllllllllllllll}0.69 & 0.72 & 0.70 & 0.43 & 0.36 & 0.28 & 0.34 & 0.36 & 0.42 & 0.37 & 0.30 & 0.29 & 0.29 & 0.32 & 0.34 & 0.26 & 0.28 & 0.24 & 0.29 & 0.29 & 0.30 & \mathrm{n} & 0.14 & 0.37\end{array}$ $\begin{array}{lllllllllllllllllllllllll}0.68 & 0.78 & 0.69 & 0.40 & 0.41 & 0.27 & 0.26 & 0.36 & 0.35 & 0.29 & 0.27 & 0.25 & 0.28 & 0.29 & 0.32 & 0.24 & 0.24 & 0.25 & 0.28 & 0.26 & 0.27 & 0.14 & n & 0.35\end{array}$ $\begin{array}{llllllllllllllllllllllll}0.72 & 0.70 & 0.69 & 0.46 & 0.43 & 0.34 & 0.30 & 0.29 & 0.38 & 0.36 & 0.30 & 0.24 & 0.23 & 0.33 & 0.29 & 0.29 & 0.30 & 0.28 & 0.31 & 0.32 & 0.35 & 0.37 & 0.35 & \mathrm{n}\end{array}$ 


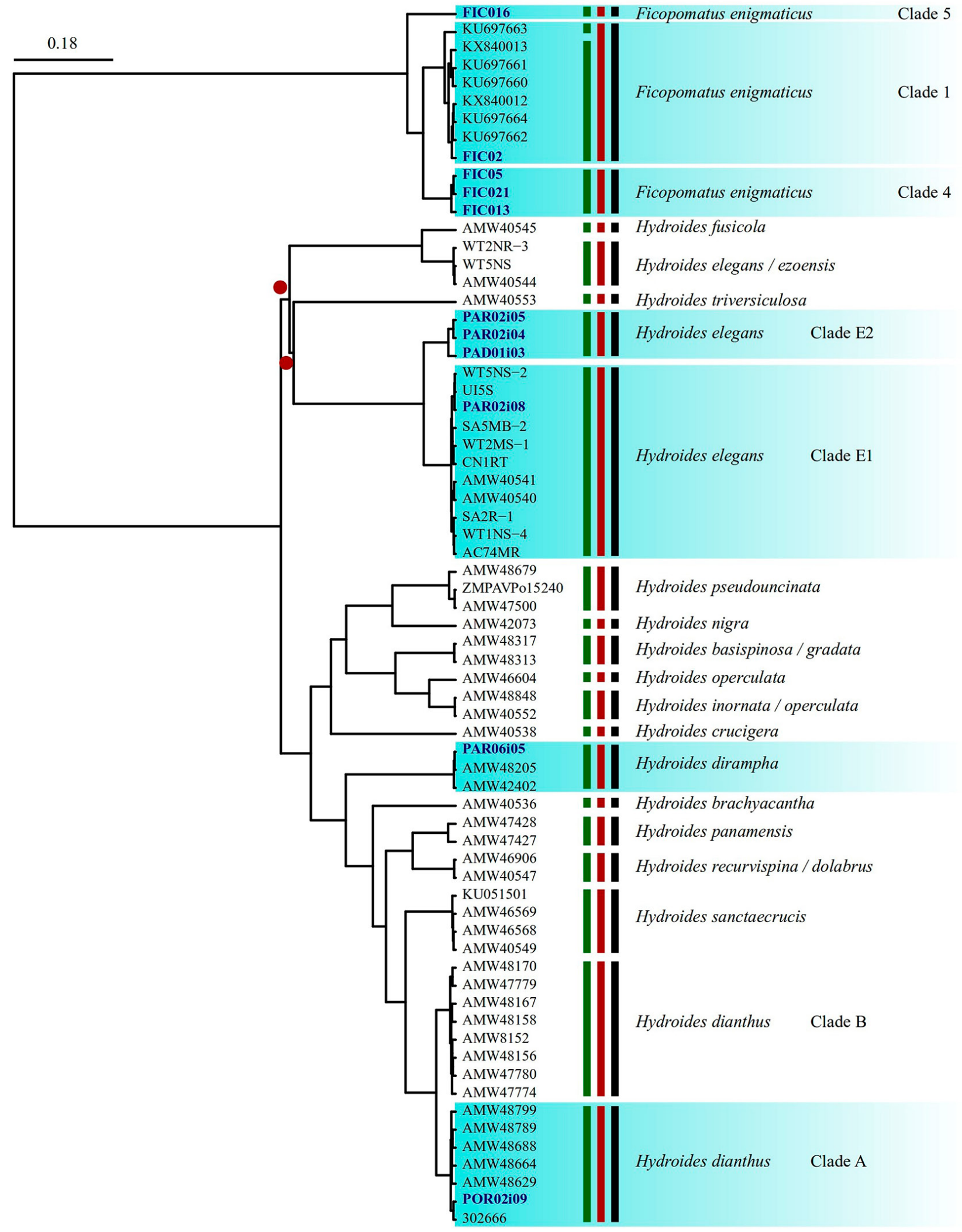

Fig. 4. - BI COI tree. Species found in Majorca are highlighted in blue. Red dots above or under branches indicate bootstrap values under 70. Specimens sequenced for this study are in bold and dark blue. GMYC entities are indicated by green lines. mPTP entities are indicated by red lines. Ficopomatus clades are named as in Styan et al. (2017). Hydroides dianthus clades are named as in Sun et al. (2017b). 
range from $21.7 \%$ to $46.3 \%$ (Table 5). This result may indicate that either of the two specimens identified as $H$. nigra from Majorca actually belongs to a different species, with morphological features similar to the diagnostic features of this species.

\section{DISCUSSION}

\section{Molecular data for assessing species diversity and invasive status}

Assessing cryptic annelid diversity after analyses of DNA sequences is now a common procedure (Nygren 2014). Previous analyses of Cytb sequences showed that $F$. enigmaticus was in fact a species complex (Styan et al. 2017, Yee et al. 2019), gathering at least two cryptic species (understood as morphologically identical but separately evolving metapopulation lineages).

Clade 1 is currently reported as widely distributed (e.g. California, Australia and Majorca) (Styan et al. 2017, Yee et al. 2019, present study). In the case of two of the lineages found in the present study, Clade 4 and Clade 5, there are no previous records of these species elsewhere, and they are for now only known from Majorca. Considering that the F. enigmaticus species complex is not originally from Mediterranean waters, they have probably been introduced, and it is also expected that members of these clades can be found in other regions worldwide. It is interesting to note that Clade 2 reported by Styan et al. (2017) and Yee et al. (2019) is recovered as two separate species in the present analyses. While we did not include all the data available for this clade in the species delimitation analyses, this suggests that molecular species delimitation is not straightforward in this group.

The situation is similar with species of Hydroides found in Majorcan waters. Both $H$. operculata and $H$. dianthus have previously been shown to be species complexes (Sun et al. 2017a,b). Hydroides dianthus Clade A has already been reported from the eastern and southern USA, Brazil, east China, Japan, Turkey and Italy. Its distribution area now includes Majorca. Although $\mathrm{H}$. dianthus was originally from the USA (Verrill 1873), it is argued that it may originate from the Mediterranean (Sun et al. 2017a). If this is confirmed, although the species has not been reported in the Balearic Islands before, it would involve reconsidering their status as invasive in Mediterranean localities. The situation is different for Hydroides cf dianthus Clade B, which has been recorded from only two places, Texas (Caribbean) and Ukraine (Black Sea), and never before in the same region as Hydroides dianthus clade A. It was suggested that this species has been introduced via the Mediterranean from an American population to the Black Sea, and our record provides more evidence in support of this hypothesis. However, previous studies of $H$. cf. dianthus Clade B were done after analyses of COI sequences, and our record uses a Cytb sequence, which limits further interpretations. (The link of the identity of sequences from these two markers was made possible by later sequencing of a voucher for more global phylogenetic purposes - see Sun et al. 2018.)

Genetic data has a great potential for detecting invasive species (Muñoz-Colmenero et al. 2018), deter- mining the source of the invasion and understanding the routes taken by the species (Geller et al. 2010, Yee et al. 2019). When encountering cryptic diversity, it is also particularly important to distinguish between the potentially invasive and native lineages. Though it was one of the aims of the present study, despite the recent progress in the COI DNA barcoding of Hydroides species (Sun et al. 2012), we encountered many difficulties in sequencing COI and Cytb from Hydroides and Ficopomatus. While the data we obtained are sufficient to detect the presence of the species complexes and identify the species present in Majorcan waters, they are not sufficient to properly assess their population structure or the sources of the invasion.

\section{Distribution of the Ficopomatus enigmaticus species complex}

The presence of $F$. enigmaticus (sensu lato) has been observed in the ports of Palma and Portitxol and near the mouth of torrents. These environments are characterized by low hydrodynamism (expect for after a large rainfall), eutrophic waters and changes in salinity. This kind of habitat has been observed previously in other studies dealing with this species (Yee et al. 2019) and conforms to the ecology of the optimal habitat for the proliferation of F. enigmaticus (sensu lato), which consists of enclosed environments with murky waters. The wide ranges of tolerance to salinity and temperature give members of this species complex the ability to establish themselves in these variant environments, unlike other serpulid species (Dittmann et al. 2009).

During the summer, there was a greater proliferation and density of $F$. enigmaticus populations, as previously observed in other studies (Vuillemin 1958, Dixon 1981). According to the literature, the minimum temperature to reproduce ranges between $14^{\circ} \mathrm{C}$ and $18^{\circ} \mathrm{C}$, which in the Balearic Islands corresponds to the month of May. The main episode of settlement and growth is between spring and summer, which correlates with an increase in biomass and carbonated production (Fornós et al. 1997). Knowing that complete maturation takes four months (Obenat and Pezzani, 1994), large aggregations may appear during the summer. The addition of the intensification of the international maritime traffic at this period increases the potential for dispersion.

\section{Distribution of the Hydroides species}

Species diversity showed an uneven presence and abundance between the locations sampled (Table 1). The most common species were $H$. dianthus and $H$. elegans, which were present at more sites within the ports of Palma, Portixol and Alcudia. Hidroides dirampha occurred in the ports of Palma, Alcudia and Sóller, and H. nigra only in Portixol (Table 1). Accordingly, the port environments with the greatest species diversity were in descending order the ports of Palma, Alcudia, Portixol and Sóller. There seems to be some correlation between the ports with the highest volume of maritime traffic (Palma, Alcudia and Portixol) and the greatest diversity of invasive species, which would conform to the expected re- 


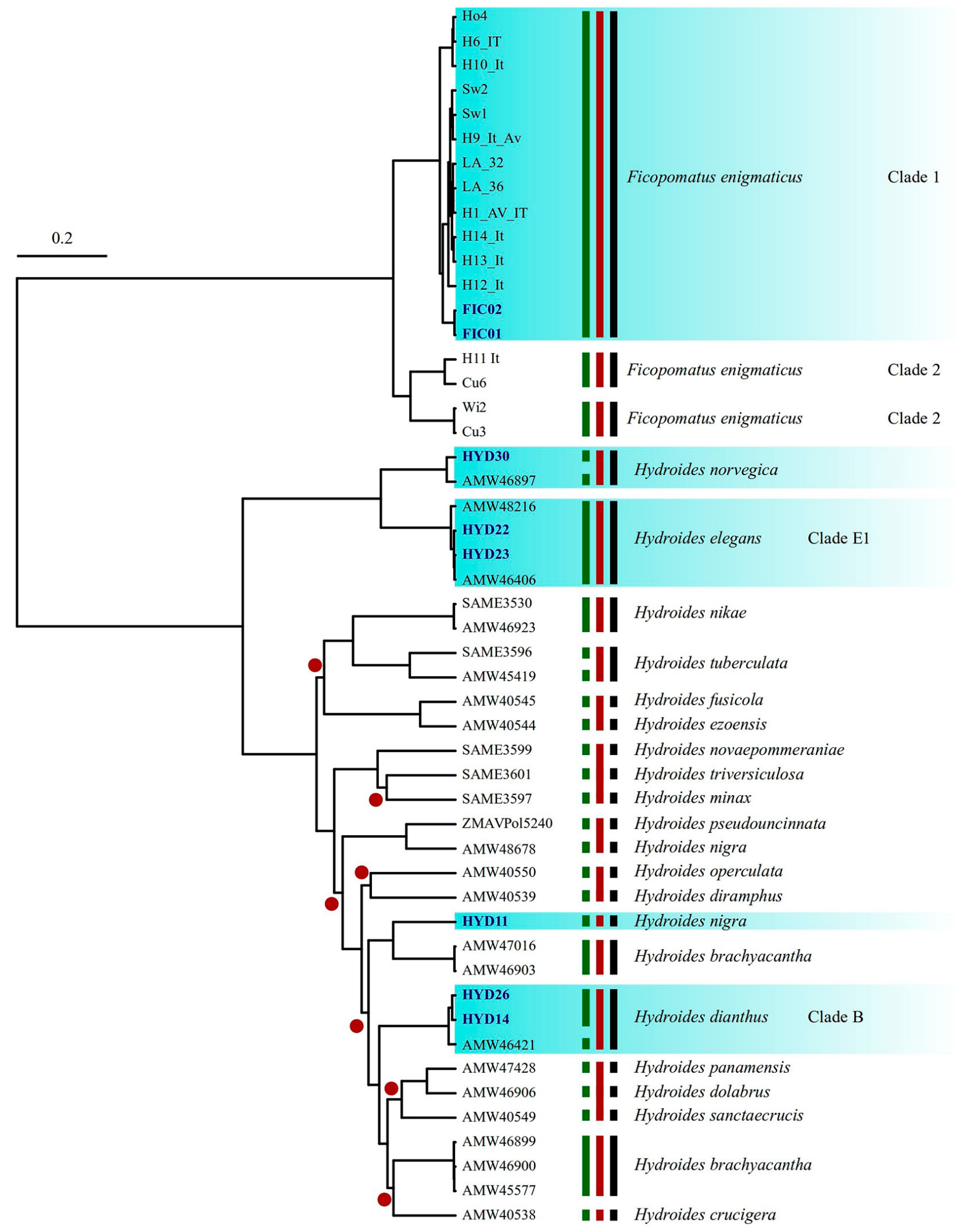

Fig. 5. - BI Cytb tree. Species found in Majorca are highlighted in blue. Red dots above or under branches indicate bootstrap values under 70. Specimens sequenced for this study are in bold and dark blue. GMYC entities are indicated by green lines. mPTP entities are indicated by red lines. Ficopomatus clades are named as in Styan et al. (2017). Hydroides dianthus clades are named as in Sun et al. (2017b). 
sults, because a greater flow of maritime transport could favour the translocation of these species associated with fouling communities embedded on the hulls of the boats (e.g. Zibrowius 1971, ten Hove and Kupriyanova 2009, Çinar 2012). In the present study, the preference of $\mathrm{Hy}$ droides for artificial substrates is verified (as in Pawlik 1992, Kupriyanova et al. 2001), with four species being present in the ports of Palma and Portixol, while none were recorded on rocky substrates in nearby anthropized areas, such as Cala Blava, and only one specimen in $\mathrm{Sa}$ Porrasa Islet (Sun et al. 2017b).

\section{CONCLUSION}

We report for the first time the presence of the Serpulidae species Ficopomatus enigmaticus, Hydroides dianthus, H. dirampha, H. elegans and $H$. nigra from Majorca. From these species, at least $F$. enigmaticus, $H$. dianthus and $H$. elegans are actually species complexes, within which at least one of the species is cosmopolitan and known as invasive. Three other species within these complexes are for now only known to Majorca and their possible status as invasive is unknown. A better knowledge of the introduction events of these species can be gained by sequencing more specimens from the archipelago.

\section{ACKNOWLEDGEMENTS}

The samples from the port of Palma, Portixol, Cala Blava and Sa Porrasa were collected as part of the project "Analysis of the marine benthic diversity in the Port of Palma and other areas of the Bay: comparison of morphological analysis and metabarcoding", financed by the Port Authority of the Balearic Islands (APB). The specimens of $H$. norvegica sequenced were collected as part of the project "Polychaetes in the Norwegian Ports: uncovering diversity in coastal anthropogenic environments and assessing cryptogenic and non-indigenous species", funded by the Norwegian Taxonomy Initiative (ABD, pnr 90262600), and we would like to thank our colleagues Torkild Bakken, Eiving Oug, Tuva Munkeby and Gunhilld Borgensen for their help in the field. We are grateful to Jaime Ros, Joel Bestard (professional divers) and Cayetana Casas (skipper of IMEDEA's boat) for their assistance. The necessary permits were requested to sample in the port areas (Port Authority, OCAE Balearic Islands, Club Náutic Sa Rápita and Port Authority of Sóller) and in the Marine Reserve of the Bay of Palma (Directorate General of Fisheries and Medi Marí, Department of Environment, Agriculture and Fishing). We are grateful to Ferran Hierro (SCT, UIB) for his assistance with the scanning electron microscope, and to Lluis Gómez-Pujol for providing us with the map of Majorca. María Capa is sponsored by the Ramón y Cajal programme (RYC-2016-20799) funded by the Spanish Ministerio de Asuntos Económicos y Transformación Digital, the Agencia Estatal de Investigación, the Comunidad Autónoma de las Islas Baleares and the European Social Fund. An early version of this manuscript was improved after the thorough comments and suggestions of two reviewers: Lena Kupriyanova and Craig Styan.

\section{REFERENCES}

Alcázar J., San Martín G. 2016. Serpúlidos (Annelida, Serpulidae) colectados en la campaña oceanográfica "Fauna II" y catálogo actualizado de especies íbero-baleares de la familia Serpulidae. Graellsia 72: e053.

Ambrogi A.O. 2000. Biotic invasions in a Mediterranean lagoon. Biol. Invasions. 2: 165-176. https://doi.org/10.1023/A:1010004926405

Aubet M.E. 2001. The Phoenicians and the West: politics, colonies and trade. Cambridge Univ. Press, 448 pp.

Autoridad Portuaria de Baleares (APB). 2017. Memoria Anual, Port de Baleares, $229 \mathrm{pp}$

Bastida-Zavala J. R., ten Hove H.A. 2002. Revision of Hydroides Gunnerus, 1768 (Polychaeta: Serpulidae) from the Western Atlantic Region. Beaufortia 52: 103-178.

Bax N., Williamson A., Aguero M., et al. 2003. Marine invasive alien species: a threat to global biodiversity. Mar. Policy 27: 313-323.

Benson D.A., Karsh-Mizrachi I., Lipman D.J., et al. 2008. GenBank. Nucleic Acids Res. 36: 25-30. https://doi.org/10.1093/nar/gkm929

Boore J.L., Brown W.M. 2000. Mitochondrial genomes of Galathealinum, Helobdella, and Platynereis: sequence and gene arrangement comparisons indicate that Pogonophora is not a phylum and Annelida and Arthropoda are not sister taxa. Mol. Biol. Evol. 17: 87-106. https://doi.org/10.1093/oxfordjournals.molbev.a026241

Bouckaert R., Heled J., Kühnert D., et al. 2014. BEAST 2: A Software Platform for Bayesian Evolutionary Analysis. PLoS Comput. Biol. 10: e1003537. https://doi.org/10.1371/journal.pcbi.1003537

Bruschetti M., Bazterrica C., Luppi T., et al. 2009. An invasive intertidal reef-forming polychaete affect habitat use and feeding behavior of migratory and locals birds in a SW Atlantic coastal lagoon. J. Exp. Mar. Biol. Ecol. 375: 76-83. https://doi.org/10.1016/j.jembe.2009.05.008

Burnette A.B., Struck T.H., Halanych K.M. 2005. Holopelagic Poeobius meseres ('Poeobiidae', Annelida) is derived from benthic flabelligerid worms. Biol. Bull-US 208: 213-220. https://doi.org/10.2307/3593153

Castresana J. 2000. Selection of conserved blocks from multiple alignments for their use in phylogenetic analysis. Mol. Biol. Evol. 17: 540-552. https://doi.org/10.1093/oxfordjournals.molbev.a026334

Çinar M. E. 2006. Serpulid species (Polychaeta: Serpulidae) from the Levantine coast of Turkey (eastern Mediterranean), with special emphasis on alien species. Aquat. Invasions 1: 223-240. https://doi.org/10.3391/ai.2006.1.4.6

Çinar M. E. 2012. Alien polychaete species worldwide: current status and their impacts J. Mar. Biolog. Assoc. U.K. 93: 12571278. https://doi.org/10.1017/S0025315412001646

Crooks J. A. 2002. Characterizing ecosystem-level consequences of biological invasions: the role of ecosystem engineers. Oikos 97: $153-166$. https://doi.org/10.1034/j.1600-0706.2002.970201.x

Davies B.R., Stuart V., De Villiers M. 1989. The filtration activity of a serpulid polychaete population (Ficopomatus enigmaticus (Fauvel)) and its effects on water quality in a coastal marina. Estuar. Coast. Shelf. Sci. 29: 613-620. https://doi.org/10.1016/0272-7714(89)90014-0

Dinno A. 2018. paran: Horn's Test of Principal Components/Factors. $\mathrm{R}$ package version 1.5.2. https://CRAN.R-project.org/package=paran

Dittmann S., Rolston A., Benger S.N., et al. 2009. Habitat requirements, distribution and colonisation of the tubeworm Ficopomatus enigmaticus in the Lower Lakes and Coorong. Report for the South Australian Murray-Darling Basin Natural Resources Management Board, Adelaide, 99 pp.

Dixon D.R. 1981. Reproductive biology of the serpulid Ficopomatus (Mercierella) enigmaticus in the Thames Estuary, SE England. J. Mar. Biol. Assoc. UK. 61: 805-815. https://doi.org/10.1017/S0025315400048220

Drummond A.J., Bouckaert R.R. 2015. Bayesian Evolutionary Analysis with BEAST. Cambridge Univ. Press. https://doi.org/10.1017/CBO9781139095112

Ergen Z. 1976. Investigations on the taxonomy and ecology of Polychaeta from Izmir Bay and its adjacent areas. Sci. Rep. Fac. Sci. Ege Univ. 209: 1-73. 
Ezard T., Fujisawa T., Barraclough T. 2017. splits: SPecies' LImits by Threshold Statistics. R package version 1.0-19/r52 https://R-Forge.R-project.org/projects/splits/

Fauvel P. 1923. Un nouveau serpulien d'eau saumatre Mercierella enigmatica $\mathrm{n}$. sp. Bull. Soc. Zool. Fr. 46: 424-430.

Fornós J.J., Forteza V., Martínez-Taberner A. 1997. Modern polychaete reefs in western Mediterranean lagoons: Ficopomatus enigmaticus (Fauvel) in the Albufera of Menorca, Balearic islands. Palaeogeogr. Palaeoclimatol. Palaeoecol. 128: 175186. https://doi.org/10.1016/S0031-0182(96)00045-4

Fujisawa T., Barraclough T.G. 2013. Delimiting species using single-locus data and the Generalized Mixed Yule Coalescent Approach: A revised method and evaluation on simulated data sets. Syst. Biol. 62: 707-724. https://doi.org/10.1093/sysbio/syt033

Geller J.B., Darling J.A., Carlton J.T. 2010. Genetic perspectives on marine biological invasions. Ann. Rev. Mar. Sci. 2: 367-393. https://doi.org/10.1146/annurev.marine.010908.163745

Geller J., Meyer C., Parker M., et al. 2013. Redesign of PCR primers for mitochondrial cytochrome c oxidase subunit I for marine invertebrates and application in all-taxa biotic surveys. Mol. Ecol. Resour. 13: 851-861. https://doi.org/10.1111/1755-0998.12138

Gil J. 2011. The European fauna of Annelida Polychaeta. $\mathrm{PhD}$ thesis, Univ. Lisboa, Portugal, 1554 pp.

Grube A.E. 1868. Beschreibungen einiger von Georg Ritter von Frauenfeld gesammelter Anneliden und Gephyreen des rothen Meeres. Verh. Zool.-Bot. Ges. Wien 18: 629-650.

Grube A.E. 1878. Annulata Semperiana. Beiträge zur Kenntniss der Annelidenfauna der Philippinen nach den von Herrn Prof. Semper mitgebrachten Sammlungen. Mem. Acad. Sci. St. Petersb. $25: 1-300$ https://doi.org/10.5962/bhl.title.85345

Guindon S., Dufayard J.F., Lefort V., et al. 2010. New algorithms and methods to estimate maximum-likelihood phylogenies: assessing the performance of PhyML 3.0. Syst. Biol. 59: 307-321. https://doi.org/10.1093/sysbio/syq010

Gunnerus J.E. 1768. Om nogle Norske coraller. Kongel. Norske Vidensk. Selsk. Skr. 4: 38-73.

Halt M.N., Kupriyanova E.K., Cooper S.J., et al. 2009. Naming species with no morphological indicators: species status of Galeolaria caespitosa (Annelida: Serpulidae) inferred from nuclear and mitochondrial gene sequences and morphology. Invertebr. Syst. 23: 205-222. https://doi.org/10.1071/IS09003

Heiman K.W., Micheli F. 2010. Non-native ecosystem engineer alters estuarine communities. Integr. Comp. Biol. 50: 226-236. https://doi.org/10.1093/icb/icq036

Hewitt C.L., Gollasch S., Minchin D. 2009. The vessel as a vector-biofouling, ballast water and sediments. In: Rilov G., Crooks J.A. (eds) Biological Invasions in Marine Ecosystems. Ecol. Stud. Springer, Berlin, Heidelberg, pp. 117-131. https://doi.org/10.1007/978-3-540-79236-9 6

Haswell W.A. 1883. On some new Australian tubicolous annelids. Proc. Linn. Soc. N.S.W. 7: 633-638.

Invasive Species Specialist Group (ISSG). 2011. We need to strengthen, not weaken, the struggle against harmful invasive species. http://www.issg.org/pdf/rebuttal.pdf

Iroso I. 1921. Revisione dei serpulidi e sabellidi del Golfo di Napoli. PSZNI Mar. Ecol. 3: 47-91.

Katsanevakis S., Wallentinus I., Zenetos A., et al. 2014. Impact of invasive alien marine species on ecosystem services and biodiversity: a pan-European review. Aquat. Invasions 9: 391-423. https://doi.org/10.3391/ai.2014.9.4.01

Kapli P., Lutteropp S., Zhang J., et al. 2017. Multi-rate Poisson tree processes for single-locus species delimitation under maximum likelihood and Markov chain Monte Carlo. Bioinformatics 33: $1630-1638$ https://doi.org/10.1093/bioinformatics/btx025

Katoh K., Standley D.M. 2013. MAFFT multiple sequence alignment software version 7: improvements in performance and usability. Mol. Biol. Evol. 30: 772-780. https://doi.org/10.1093/molbev/mst010

Kearse M., Moir R., Wilson A., et al. 2012. Geneious Basic: an integrated and extendable desktop software platform for the organization and analysis of sequence data. Bioinformatics 28 : $1647-1649$.

https://doi.org/10.1093/bioinformatics/bts199
Kumar S., Stecher G., Li M., et al. 2018. MEGA X: Molecular Evolutionary Genetics Analysis across computing platforms. Mol. Biol. Evol. 35: 1547-1549. https://doi.org/10.1093/molbev/msy096

Kupriyanova E.K., Nishi E., ten Hove H.A., et al. 2001. A review of life history patterns in Serpulimorph polychaetes: ecological and evolutionary perspectives. Oceanogr. Mar. Biol. 39: 1-101.

Lanfear R., Frandsen P.B., Wright A.M., et al. 2016. PartitionFinder 2: New methods for selecting partitioned models of evolution for molecular and morphological phylogenetic analyses. Mol. Biol. Evol. 34: 772-773. https://doi.org/10.1093/molbev/msw260

Larsson A. 2014. AliView: a fast and lightweight alignment viewer and editor for large datasets. Bioinformatics 30: 3276-3278. https://doi.org/10.1093/bioinformatics/btu531

Martínez-Taberner A., Forteza V., Fornós J.J. 1993. Colonization, structure and growth of Ficopomatus enigmaticus $\mathrm{cf}$. ten Hove and Weerdenburg (Polychaeta, Serpulidae) in the Albufera of Menorca, Balearic Islands. Verh. Internat. Verein. Limnol. 25: 1031-1034. https://doi.org/10.1080/03680770.1992.11900316

Miller M.A., Pfeiffer W., Schwartz T. 2010. Creating the CIPRES Science Gateway for Inference of Large Phylogenetic Trees. In: Proceedings of the Gateway Computing Environments Workshop. New Orleans, pp. 1-8. https://doi.org/10.1109/GCE.2010.5676129

Molnar J.L., Gamboa R.L., Revenga C., et al. 2008. Assessing the global threat of invasive species to marine biodiversity. Front. Ecol. Environ. 6: 485-492. https://doi.org/10.1890/070064

Mörch O. A. L. 1863. Revisio critica Serpulidarum. Et Bidrag til Rørormenes Naturhistorie. Naturh. Tidsskr. København 3: $347-470$.

Muñoz-Colmenero M., Ardura A., Clusa L., et al. 2018. New specific molecular marker detects Ficopomatus enigmaticus from water eDNA before positive results of conventional sampling. J. Nat. Conserv. 43: 173-178. https://doi.org/10.1016/j.jnc.2017.12.004

Nygren A. 2014. Cryptic polychaete diversity: a review. Zool. Scr. 43: 172-183. https://doi.org/10.1111/zsc.12044

Obenat S.M., Pezzani S.E. 1994. Life cycle and population structure of the polychaete Ficopomatus enigmaticus (Serpulidae) in Mar Chiquita coastal lagoon, Argentina. Estuaries 17: 263. https://doi.org/10.2307/1352574

Oliva M., De Marchi L., Vieira Sanches M., et al. 2020. Atlantic and Mediterranean populations of the widespread serpulid Ficopomatus enigmaticus: Developmental responses to carbon nanotubes. Mar. Poll. Bull. 156: 111265. https://doi.org/10.1016/i.marpolbul.2020.111265

Pan J., Marcoval M.A. 2013. Top-down effects of an exotic serpulid polychaete on natural plankton assemblage of estuarine and brackish systems in the SW Atlantic. J. Coast. Res. 30: 1226-1235. https://doi.org/10.2112/JCOASTRES-D-12-00163.1

Paradis E., Schliep K. 2018. ape 5.0: an environment for modern phylogenetics and evolutionary analyses in R. Bioinformatics 35: 526-528. https://doi.org/10.1093/bioinformatics/bty633

Pawlik J.R. 1992. Chemical ecology of the settlement of benthic marine invertebrates. Oceanogr. Mar. Biol. 30: 273-335.

Peria J., Pernet B. 2019. Tolerance to salinity and thermal stress by larvae and adults of the serpulid annelid Ficopomatus enigmaticus. Invertebr. Biol. 138: e12271. https://doi.org/10.1111/ivb.12271

Pernet B., Barton M., Fitzhugh K., et al. 2016. Establishment of the reef-forming tubeworm Ficopomatus enigmaticus (Fauvel, 1923) (Annelida: Serpulidae) in southern California. Bioinvasions Rec. 5 https://doi.org/10.3391/bir.2016.5.1.03

Philippi A. 1844. Einige Bemerkungen über die Gattung Serpula, nebst Aufzählung der von mir im Mittelmeer mit dem Thier beobachteten Arten. Archiv für Naturgeschichte Berlin. 10: 186-198. https://doi.org/10.5962/bhl.part.29558

Pons J., Barraclough T.G., Gomez-Zurita J., et al. 2006. Sequence-based species delimitation for the DNA taxonomy of undescribed insects. Syst. Biol. 55: 595-609. https://doi.org/10.1080/10635150600852011 
R Core Team. 2015. R: A language and environment for statistical computing. R Foundation for Statistical Computing, Vienna, Austria. https://www.R-project.org/

Rafinesque C.S. 1815. Analyse de la nature ou tableau de l'univers et des corps organisés. Palermo, 224 pp. https://doi.org/10.5962/bhl.title.106607

Rambaut A. 2014. FigTree 1.4.2 Software. Institute of Evolutionary Biology, Univ. Edinburgh, Edinburgh.

Rambaut A., Drummond A.J., Xie D., et al. 2018. Posterior Summarization in Bayesian Phylogenetics Using Tracer 1.7. Syst. Biol. 67: 901-904. https://doi.org/10.1093/sysbio/syy032

Read G.B., Gordon D.P. 1991. Adventive occurrence of the fouling serpulid Ficopomatus enigmaticus (Polychaeta) in New Zealand. N. Z. J. Mar. Freshw. Res. 25: 269-273. https://doi.org/10.1080/00288330.1991.9516478

Rioja E. 1923. Estudio sistemático de las especies Ibéricas del suborden Sabelliformia. Trab. Mus. Natl. Cienc. Nat. Ser. Zool. 48: 1-144.

Rioja E. 1941. Estudios Anelidologicos. II. Observaciones acerca de varias especies del genero Hydroides Gunnerus (sensu Fauvel) de las costas Mexicanas del Pacífico. An. Inst. Biol. Mex. 12: 161-175.

Rodriguez L.F. 2006. Can invasive species facilitate native species? Evidence of how, when, and why these impacts occur. Biol. Invasions 8: 927-939. https://doi.org/10.1007/s10530-005-5103-3

San Martín G., Viéitez J.M. 1984. Anélidos poliquetos de los rizomas de Posidonia oceanica, en las costas de Cabo de Palos (Murcia, España). In: Bodouresque et al. (eds), International Workshop Posidonia oceanica Beds, GIS Posidonie publ. pp. 149-157.

Schwindt E., Bortolus A., Iribarne O.O. 2001. Invasion of a reef-builder polychaete: direct and indirect impacts on the native benthic community structure. Biol. Invasions 3: 137-149. https://doi.org/10.1023/A:1014571916818

Schwindt E., De Francesco C.G., Iribarne O.O. 2004. Individual and reef growth of the invasive reef-building polychaete $F i$ copomatus enigmaticus in a south-western Atlantic coastal lagoon. J. Mar. Biol. Assoc. UK. 84: 987-993. https://doi.org/10.1017/S0025315404010288h

Shumka S., Kashta L., Cake A. 2014. Occurrence of the nonindigenous tubeworm Ficopomatus enigmaticus (Fauvel, 1923) (Polychaeta: Serpulidae) on the Albanian coast of the Adriatic Sea. Turk. J. Zool. 38: 519-521. https://doi.org/10.3906/zoo-1303-14

Smith A. M., Henderson Z. E., Kennedy M., et al. 2012. Reef formation versus solitariness in two New Zealand serpulids does not involve cryptic species. Aquat. Biol. 16: 97-103. https://doi.org/10.3354/ab00444

Styan C.A., McCluskey C.F., Sun Y., et al. 2017. Cryptic sympatric species across the Australian range of the global estuarine invader Ficopomatus enigmaticus (Fauvel, 1923) (Serpulidae, Annelida). Aquat. Invasions 12: 53-65. https://doi.org/10.3391/ai.2017.12.1.06

Sun Y., Kupriyanova E.K., Qiu J.W. 2012. COI barcoding of $H y$ droides: a road from impossible to difficult. Invertebr. Syst. 26: 539-547. https://doi.org/10.1071/IS12024

Sun Y., Wong E., Tovar-Hernández M.A., et al. 2016. Is Hydroides brachyacantha (Serpulidae: Annelida) a widespread species? Invertebr. Syst. 30: 41-59. https://doi.org/10.1071/IS15015

Sun Y., Wong E., Keppel E., et al. 2017a. A global invader or a complex of regionally distributed species? Clarifying the status of an invasive calcareous tubeworm Hydroides dianthus (Verrill 1873) (Polychaeta: Serpulidae) using DNA barcoding. Mar. Biol. 164: 28. https://doi.org/10.1007/s00227-016-3058-9

Sun Y., Al-Kandari M., Kubal P., et al. 2017b. Cutting a gordian knot of tubeworms with DNA data: the story of the Hydroides operculata-complex (Annelida, Serpulidae). Zootaxa 4323: 39-48 https://doi.org/10.11646/zootaxa.4323.1.3

Sun Y., Wong E., Ayhong S.T., et al. 2018 Barcoding and multi-locus phylogeography of the globally distributed calcareous tubeworm Hydroides Gunnerus, 1768 (Annelida, Polychaeta, Serpulidae). Mol. Phy. Evol. 127: 732-745. https://doi.org/10.1016/j.ympev.2018.06.021
Ten Hove H.A., Kupriyanova E.K. 2009. Taxonomy of Serpulidae (Annelida, Polychaeta): The state of affairs. Zootaxa 2036: 1-126. https://doi.org/10.11646/zootaxa.2036.1.1

Toonen R.J., Pawlik J.R. 2001. Foundations of gregariousness: A dispersal polymorphism among the planktonic larvae of a marine invertebrate. Evolution 55: 2439-2454. https://doi.org/10.1111/j.0014-3820.2001.tb00759.x

Treadwell A.L. 1929. New species of polychaetous annelids in the collections of the American Museum of Natural History from Porto Rico, Florida, Lower California, and British Somaliland. Am. Mus. Novit. 392: 1-13. https://doi.org/10.5479/si.00963801.75-2797.1

Ulman A., Ferrario J., Occhpinti-Ambrogi A., et al. 2017. A massive update of non-indigenous species records in Mediterranean marinas. PeerJ. 5: e3954. https://doi.org/10.7717/peerj.3954

Ulman A., Ferrario J., Forcada A., et al. 2019. Alien species spreading via biofouling on recreational vessels in the Mediterranean Sea. J. Appl. Ecol. 56: 2620-2629. https://doi.org/10.1111/1365-2664.13502

Venables W.N., Ripley B.D. 2002. Modern applied statistics with S. Fourth Edition, Springer, New York. https://doi.org/10.1007/978-0-387-21706-2

Verrill A.E. 1873. XVIII. Report upon the invertebrate animals of Vineyard Sound and the adjacent waters, with an account of the physical characters of the region. Report on the condition of the sea fisheries of the south coast of New England in 1871 and 1872. Washington Gov. Print. Off. pp. $295-778$. https://doi.org/10.5962/bhl.title.57652

Vuillemin S. 1958. Fixation obtenue au laboratoire des larves de quelques Serpuliens (Annélides Polychètes) du lac de Tunis. C. R. Acad. Hebd. Seances Acad. Sci. D. 247: 20382040.

Willette D.A., Iñiguez A.R., Kupriyanova E.K., et al. 2015. Christmas tree worms of Indo-Pacific coral reefs: untangling the Spirobranchus corniculatus (Grube, 1862) complex. Coral Reefs 34: 899-904. https://doi.org/10.1007/s00338-015-1294-y

Wright J.T., Gribben P.E. 2017. Disturbance-mediated facilitation by an intertidal ecosystem engineer. Ecology 98: 2425-2436. https://doi.org/10.1002/ecy.1932

Yee A., Mackie J., Pernet B. 2019. The distribution and unexpected genetic diversity of the non-indigenous annelid Ficopomatus enigmaticus in California. Aquat. Invasions 14: 250-266. https://doi.org/10.3391/ai.2019.14.2.06

Zenetos A., Çinar M.E., Pancucci-Papadopoulou M.A., et al. 2005. Annotated list of marine alien species in the Mediterranean with records of the worst invasive species. Mediterr. Mar. Sci. 6: 63-118. https://doi.org/10.12681/mms.186

Zibrowius H. 1968. Étude morphologique, systématique et écologique des Serpulidae (Annelida Polychaeta) de la région de Marseille. Rec. Trav. Station mar. Endoume 43: 81-252.

Zibrowius H. 1971. Les espèces Méditerrannéennes du genre Hydroides (Polychaeta Serpulidae). Remarques sur le prétendu polymorphisme de Hydroides uncinata. Téthys 2 : 691-746.

Zibrowius H. 1991. Ongoing modification of the Mediterranean marine fauna and flora by the establishment of exotic species. Mésogée 51: 83-107.

Zibrowius H. 2002. Assessing scale and impact of ship-transported alien fauna in the Mediterranean? CIESM Workshop Monographs 20: 62-68.

\section{SUPPLEMENTARY MATERIAL}

The following supplementary material is available through the online version of this article and at the following link: http://scimar.icm.csic.es/scimar/supplm/ sm05062esm.pdf

Table S1. - Collection information on the specimens used for the phylogenetic analyses, vouchers, and GenBank accession numbers. 


\section{The elephant in the room: first record of invasive gregarious species of serpulids (calcareous tube annelids) in Majorca (western Mediterranean)}

Maël Grosse, Roberto Pérez, Mateo Juan-Amengual, Joan Pons, María Capa

Supplementary material 
Table S1. - Collection information on the specimens used for the phylogenetic analyses, vouchers, and GenBank accession numbers.

\begin{tabular}{|c|c|c|c|c|}
\hline$\overline{\text { Species }}$ & Voucher / ID & Locality & COI & Cytb \\
\hline Hydroides triversiculosus & AMW40553 / SAME3601 & Australia & JQ885940 & EU190476 \\
\hline Hydroides basispinosa & AMW48317 & Australia & MF405948 & \\
\hline Hydroides gradata & AMW48313 & Australia & MF405959 & \\
\hline Hydroides operculata & AMW40552 & China & JQ885948 & \\
\hline Hydroides operculata & AMW40550 & China & & KP178722 \\
\hline Hydroides inornata & AMW48848 & India & MF405941 & \\
\hline Hydroides operculata & AMW46604 & Kuwait & MF405954 & \\
\hline Hydroides nigra & AMW42073 & Spain & MF405952 & \\
\hline Hydroides pseudouncinata & AMW48679 & Spain & MF405946 & \\
\hline Hydroides pseudouncinata & ZMAVPol5240 & France & KP178713 & EU190467 \\
\hline Hydroides pseudouncinata & AMW47500 & Greece & MF405945 & \\
\hline Hydroides diramphus & AMW40539 & China & & KP178718 \\
\hline Hydroides crucigera & AMW40538 & Mexico & JQ885947 & KP178715 \\
\hline Hydroides branchyacanthus & AMW40536 & Mexico & JQ885941 & \\
\hline Hydroides recurvispina & AMW40547 & Mexico & JQ885945 & \\
\hline Hydroides dolabrus & AMW46906 & Mexico & KP178712 & KP178719 \\
\hline Hydroides panamensis & AMW47428 & Costa Rica & & KP988293 \\
\hline Hydroides sanctaecrucis & AMW46569 & Australia & KU051504 & \\
\hline Hydroides sanctaecrucis & AMW40549 & Mexico & JQ885943 & KP178717 \\
\hline Hydroides sanctaecrucis & & Australia & KU051501 & \\
\hline Hydroides sanctaecrucis & AMW46568 & Australia & KU051503 & \\
\hline Hydroides dianthus & AMW48799 & Turkey & KY123243 & \\
\hline Hydroides dianthus & AMW48789 & Turkey & KY123249 & \\
\hline Hydroides dianthus & AMW48688 & Italy & KY386653 & \\
\hline Hydroides dianthus & AMW48664 & Italy & KY386640 & \\
\hline Hydroides dianthus & AMW48629 & Italy & KY386635 & \\
\hline Hydroides dianthus & 302666 & USA & KU051463 & \\
\hline Hydroides dianthus & AMW48170 & Ukraine & KU051522 & \\
\hline Hydroides dianthus & AMW47779 & USA & KU051477 & \\
\hline Hydroides dianthus & AMW48167 & Ukraine & KU051521 & \\
\hline Hydroides dianthus & AMW48156 & USA & KU051512 & \\
\hline Hydroides dianthus & AMW47774 & USA & KU051472 & \\
\hline Hydroides dianthus & AMW48152 & USA & KU051508 & \\
\hline Hydroides dianthus & AMW48158 & USA & KU051514 & \\
\hline Hydroides dianthus & AMW47780 & USA & KU051478 & \\
\hline Hydroides fusicola & AMW40545 & Japan & JQ885950 & KP178723 \\
\hline Hydroides elegans & WT2NR-3 & Australia & MH339602 & \\
\hline Hydroides ezoensis & AMW40544 & Russia & JQ885951 & KP178716 \\
\hline Hydroides elegans & WT5NS & Australia & MH339603 & \\
\hline Hydroides elegans & AMW40541 & Australia & JQ885939 & \\
\hline Hydroides elegans & SA5MB-2 & USA & KY235613 & \\
\hline Hydroides elegans & AMW40540 & China & JQ885938 & \\
\hline Hydroides elegans & WT1NS-4 & Australia & MH339601 & \\
\hline Hydroides elegans & UI5S & USA & KY235618 & \\
\hline Hydroides elegans & WT5NS-2 & Australia & MH339600 & \\
\hline Hydroides elegans & WT2MS-1 & Australia & MH339596 & \\
\hline Hydroides elegans & CN1RT & USA & KY235603 & \\
\hline Hydroides elegans & AC74MR & USA & KY235596 & \\
\hline Hydroides elegans & SA2R-1 & USA & KY235607 & \\
\hline Ficopomatus enigmaticus & KU697663 & Spain & KU697663 & \\
\hline Ficopomatus enigmaticus & KU697660 & Spain & KU697660 & \\
\hline Ficopomatus enigmaticus & KU697661 & Spain & KU697661 & \\
\hline Ficopomatus enigmaticus & KU697662 & Spain & KU697662 & \\
\hline Ficopomatus enigmaticus & KU697664 & Spain & KU697664 & \\
\hline Ficopomatus enigmaticus & KX840012 & Spain & KX840012 & \\
\hline Ficopomatus enigmaticus & KX840013 & Spain & KX840013 & \\
\hline Ficopomatus enigmaticus & $\mathrm{Cu} 3$ & Australia & & KP863760 \\
\hline Ficopomatus enigmaticus & Wi2 & Australia & & KP863759 \\
\hline Ficopomatus enigmaticus & Ho4 & Australia & & KP863758 \\
\hline Ficopomatus enigmaticus & H10_It & Italy & & MK934530 \\
\hline Ficopomatus enigmaticus & H14_It & Italy & & MK934534 \\
\hline
\end{tabular}




\begin{tabular}{|c|c|c|c|c|}
\hline Species & Voucher / ID & Locality & $\mathrm{COI}$ & Cytb \\
\hline Ficopomatus enigmaticus & H13_It & Italy & & MK934533 \\
\hline Ficopomatus enigmaticus & H12_It & Italy & & MK934532 \\
\hline Ficopomatus enigmaticus & $\mathrm{Sw} \overline{2}$ & Australia & & KP863738 \\
\hline Ficopomatus enigmaticus & Sw1 & Australia & & KP863736 \\
\hline Ficopomatus enigmaticus & H9_It_Av & Italy / Portugal & & MK934529 \\
\hline Ficopomatus enigmaticus & LA_36 & USA & & MK334109 \\
\hline Ficopomatus enigmaticus & LA_32 & USA & & MK334105 \\
\hline Ficopomatus enigmaticus & $\overline{\mathrm{Cu}} 6$ & Australia & & KP863767 \\
\hline Ficopomatus enigmaticus & H11_It & Italy & & MK934531 \\
\hline Hydroides norvegica & AMW4̄6897 & Norway & & KP178721 \\
\hline Hydroides tuberculata & SAME3596 & & & EU190473 \\
\hline Hydroides tuberculata & AMW45419 & Australia & & KR095099 \\
\hline Hydroides minax & SAME3597 & & & EU190475 \\
\hline Hydroides nikae & SAME3530 & & & EU190466 \\
\hline Hydroides nikae & AMW46923 & Australia & & KR095078 \\
\hline Hydroides brachyachanta & AMW45577 & Mexico & & KR095053 \\
\hline Hydroides brachyachanta & AMW46899 & Mexico & & KR095068 \\
\hline Hydroides brachyachanta & AMW46900 & Mexico & & KR095069 \\
\hline Hydroides brachyachanta & AMW47016 & Mexico & & KR095089 \\
\hline Hydroides brachyachanta & AMW46903 & Mexico & & KR095070 \\
\hline Hydroides novaepommeraniae & SAME3599 & & & EU190478 \\
\hline Ficopomatus enigmaticus & H1_AV_IT & Italy / Portugal & & MH271215 \\
\hline Ficopomatus enigmaticus & H6_IT & Italy & & MH271220 \\
\hline Hydroides nigra & AM W48678 & Spain & & MF406020 \\
\hline Hydroides elegans & AMW48216 & USA & & MG892710 \\
\hline Hydroides elegans & AM W46406 & & & MG892708 \\
\hline Hydroides dirampha & AM W48205 & Panama & MG892525 & \\
\hline Hydroides dirampha & AM W42402 & Australia & MG892524 & \\
\hline Ficopomatus enigmaticus & FIC01 - MNCN 16.01/18765 & Majorca & MT044486 & MT215015 \\
\hline Ficopomatus enigmaticus & FIC02 - MNCN 16.01/18766 & Majorca & MT044489 & MT215014 \\
\hline Ficopomatus enigmaticus & FIC04-MNCN 16.01/18767 & Majorca & MT044492 & NA \\
\hline Ficopomatus enigmaticus & FIC05 - MNCN 16.01/18768 & Majorca & MT044491 & NA \\
\hline Ficopomatus enigmaticus & FIC12 - MNCN 16.01/18769 & Majorca & MT044494 & NA \\
\hline Ficopomatus enigmaticus & FIC15 - MNCN 16.01/18770 & Majorca & MT044488 & NA \\
\hline Ficopomatus enigmaticus & FIC16 - MNCN 16.01/18771 & Majorca & MT044495 & NA \\
\hline Ficopomatus enigmaticus & FIC17 - MNCN 16.01/18772 & Majorca & MT044490 & NA \\
\hline Ficopomatus enigmaticus & FIC20 - MNCN 16.01/18773 & Majorca & MT044487 & NA \\
\hline Ficopomatus enigmaticus & FIC21 - MNCN 16.01/18774 & Majorca & MT044493 & NA \\
\hline Hydroides nigra & HYD11 - MNCN 16.01/18775 & Majorca & NA & MT215009 \\
\hline Hydroides dianthus & HYD14 - MNCN 16.01/18776 & Majorca & NA & MT215010 \\
\hline Hydroides elegans & HYD22 & Majorca & NA & MT215012 \\
\hline Hydroides elegans & HYD23 - MNCN 16.01/18777 & Majorca & NA & MT215008 \\
\hline Hydroides dianthus & HYD26 - MNCN 16.01/18778 & Majorca & NA & MT215011 \\
\hline Hydroides norvegica & HYD30 & Norway & NA & MT215013 \\
\hline Hydroides dirampha & PAR06i05 - MNCN 16.01/18779 & Majorca & MT044496 & NA \\
\hline Hydroides dianthus & POR02i09 - MNCN 16.01/18780 & Majorca & MT044497 & NA \\
\hline Hydroides elegans & PAR02i05 - MNCN 16.01/18781 & Majorca & MT044498 & NA \\
\hline Hydroides elegans & PAR02i04 - MNCN 16.01/18782 & Majorca & MT044499 & NA \\
\hline Hydroides elegans & PAD01i03 - 16.01/18783 & Majorca & MT044500 & NA \\
\hline Hydroides elegans & PAR02i08 - MNCN 16.01/18784 & Majorca & MT044501 & NA \\
\hline
\end{tabular}

